\title{
Neuromuscular training to enhance sensorimotor and functional deficits in subjects with chronic ankle instability: A systematic review and best evidence synthesis
}

\author{
Jeremiah O'Driscoll ${ }^{1}$ and Eamonn Delahunt ${ }^{2,3^{*}}$
}

\begin{abstract}
Objective: To summarise the available evidence for the efficacy of neuromuscular training in enhancing sensorimotor and functional deficits in subjects with chronic ankle instability (CAl).

Design: Systematic review with best evidence synthesis.

Data Sources: An electronic search was conducted through December 2009, limited to studies published in the English language, using the Pubmed, CINAHL, Embase, and SPORTDiscus databases. Reference screening of all included articles was also undertaken.

Methods: Studies were selected if the design was a RCT, quasi RCT, or a CCT; the patients were adolescents or adults with confirmed CAl; and one of the treatment options consisted of a neuromuscular training programme. The primary investigator independently assessed the risk of study bias and extracted relevant data. Due to clinical heterogeneity, data was analysed using a best-evidence synthesis.

Results: Fourteen studies were included in the review. Meta-analysis with statistical pooling of data was not possible, as the studies were considered too heterogeneous. Instead a best evidence synthesis was undertaken. There is limited to moderate evidence to support improvements in dynamic postural stability, and patient perceived functional stability through neuromuscular training in subjects with CAl. There is limited evidence of effectiveness for neuromuscular training for improving static postural stability, active and passive joint position sense (JPS), isometric strength, muscle onset latencies, shank/rearfoot coupling, and a reduction in injury recurrence rates. There is limited evidence of no effectiveness for improvements in muscle fatigue following neuromuscular intervention.
\end{abstract}

Conclusion: There is limited to moderate evidence of effectiveness in favour of neuromuscular training for various measures of static and dynamic postural stability, active and passive JPS, isometric strength, muscle onset latencies, shank/rearfoot coupling and injury recurrence rates. Strong evidence of effectiveness was lacking for all outcome measures. All but one of the studies included in the review were deemed to have a high risk of bias, and most studies were lacking sufficient power. Therefore, in future we recommend conducting higher quality RCTs using appropriate outcomes to assess for the effectiveness of neuromuscular training in overcoming sensorimotor deficits in subjects with CAl.

Keywords: ankle sprain, ankle instability, ankle injury, rehabilitation, injury prevention

\footnotetext{
* Correspondence: eamonn.delahunt@ucd.ie

${ }^{2}$ School of Public Health, Physiotherapy and Population Science, University

College Dublin, Dublin, Ireland

Full list of author information is available at the end of the article
} 


\section{Introduction}

The ankle joint is the second most common injured body site in sport with lateral ankle sprains being the most common type of ankle injury [1]. Thus, ankle sprains are one of the most frequently encountered musculoskeletal injuries. Ankle sprains, account for between 3\% and 5\% of all Emergency Department attendances in the UK, with about 5,600 incidences per day [2]. It is probable that many more attend primary care facilities, such as General Practitioners and sports clinics, and thus the true incidence may well be underestimated. In the acute phase, ankle sprains are associated with pain and loss of function, and one quarter of all injured people are unable to attend school or work for more than seven days [3].

Unfortunately, the current misconception is that ankle sprains are simple innocuous injuries. This misconception is ill placed and up to $30 \%$ of people who incur a "simple" ankle sprain will report persistent symptoms such as pain, swelling, decreased function, feelings of ankle joint instability and recurrent sprains. The generic term for these persistent symptoms is chronic ankle instability (CAI).

CAI has recently been defined as an encompassing term used to classify a subject with both mechanical and functional instability of the ankle joint [4]. Furthermore according to the definition put forth by Delahunt et al [4], to be classified as having CAI, residual symptoms such as episodes of ankle joint "giving way" and feelings of ankle joint instability should be present for a minimum of 1 year post-initial sprain. Mechanical instability (MI) of the ankle joint is characterized by excessive inversion laxity of the rear foot or excessive anterior laxity of the talocrural joint. As a result, joint range of motion is beyond the normal expected physiological or accessory range of motion for that joint [4]. Functional instability (FI) of the ankle joint refers to a situation whereby a subject reports experiencing frequent episodes of ankle joint "giving way" and feelings of ankle joint instability [4].

The well accepted paradigm put forth by Hertel [5] suggests that the development of CAI is dependent upon the interaction of various mechanical and sensorimotor insufficiencies. Mechanical insufficiencies include excessive joint laxity, restricted accessory joint gliding and micro-subluxations. Sensorimotor insufficiencies include alterations in muscle activation patterns, impaired postural stability, and altered movement patterns during gait and other functional activities.

The high rate of ankle sprains sustained during activities of daily living, occupational endeavour and across all sports, as well as the severity and subsequent negative consequences associated with the development of
CAI motivates attention for preventive measures against this type of injury. Exercises to improve neuromuscular control in subjects with CAI are advocated throughout the literature [6-10], yet there remains little unequivocal evidence regarding their effectiveness. Therefore, the primary aim of this systematic review was to assess the efficacy of neuromuscular training in enhancing sensorimotor function in subjects with CAI.

\section{Methodology \\ Literature Search}

The literature search was conducted in two stages. For stage one, an initial electronic search was performed and studies were evaluated for inclusion. Stage two consisted of a hand search of the reference lists of the articles selected in stage one. The electronic search using pre-defined search terms was restricted to English-language publications found in the following databases through December 2009: PubMed (National Library of Medicine, Bethesda, MD), Embase, CINAHL, and SPORTDiscus. The latter two databases were searched simultaneously using EBSCOhost (EBSCO Industries, Inc, Birmingham, AL). The reference lists of all included articles were then checked for additional pertinent studies. The primary investigator (PI) conducted the search (see additional file 1)

\section{Article Inclusion and Exclusion Criteria}

Once the search had been completed, titles and abstracts of the retrieved articles were reviewed by the PI. For final inclusion the articles had to fulfil all of the following criteria:

1) study design had to be either a randomized controlled trial (RCT), a quasi RCT, or a clinical controlled trial $(\mathrm{CCT})$.

2) one of the treatment options had to consist of a neuromuscular training programme (e.g. postural stability training, strength training, etc).

3) each study had to use an inclusion criterion of giving way or frequent sprains, or to have described the target condition as functional ankle instability (FAI), FI or CAI.

Studies using mixed group design (i.e. groups containing subjects with CAI/FI and healthy controls) were excluded from the review. Studies which assessed the additional effect of adjunctive therapies to neuromuscular training such as taping and stochastic resonance $[6,10]$ were included. However for such studies (i.e. studies examining the additional effect of adjunctive therapies), results and effect sizes were acquired for the neuromuscular training groups only. The additional 
effects of adjunctive interventions were deemed to be beyond the scope of this study.

\section{Risk of Bias Assessment}

Risk of bias in the included studies was assessed by the PI, using the Cochrane collaboration's tool for assessing such risk [11]. This tool was adapted for the objective of this review and consists of 5 domains, with 11 items in total (see additional file 2). Each item was rated as 'yes', 'no', or 'unsure'. Studies with 6 or more points on the risk of bias assessment were regarded as having a low risk of bias. This risk of bias tool has previously been utilised by van Rijn et al [12] to investigate the effectiveness of additional supervised exercises compared to conventional treatment alone in patients with acute ankle sprains.

\section{Data Extraction}

The PI extracted relevant data from the included studies. The study characteristics extracted included information on the target population (gender, history of the condition, sample size etc.), presence of concomitant MI, training protocols implemented, outcome measures and significant findings. In cases of uncertainty about the extracted data from the included studies a second reviewer was consulted.

Where feasible the core findings of each article were expressed as effect sizes (ES). If possible, these measures were extracted directly from the article. For articles in which this information was not presented, as was generally the case, effect sizes were calculated using mean values and a pooled standard deviation in accordance with the methods described by Cohen [13]. Effect sizes between 0.2 and 0.49 can be interpreted as weak, 0.5 to 0.79 as medium, and greater than 0.8 as strong [13]. Furthermore, $95 \%$ confidence intervals were also calculated.

Outcome measures were grouped into the following categories:

- Static postural stability

- Dynamic postural stability

- Joint position sense

- Strength measures

- Muscle onset latencies

- Joint kinematic data

- Muscle fatigue values

- Patient perceived stability

\section{Data Analysis}

The main comparisons of this review were time (i.e. pre and post intervention within the CAI group), and group (i.e. between CAI group and control group) training effects of various neuromuscular training programmes on commonly used sensorimotor outcomes to assess for treatment efficacy in subjects with CAI. Due to the clinical heterogeneity of the trials concerning population, intervention and outcome measures, statistical pooling was not possible. Therefore the data was analysed using a best evidence synthesis as advocated by van Tulder et al [14]. This rating system consists of 4 levels of scientific evidence based on the quality of the included studies:

1) Strong evidence; provided by generally consistent findings in multiple RCTs assessed as having low risk of bias.

2) Moderate evidence; provided by generally consistent findings in one RCT assessed as having low risk of bias, and one or more RCTs assessed as having high risk of bias, or by generally consistent findings in multiple RCTs assessed as having high risk of bias.

3) Limited or conflicting evidence; only one RCT (assessed as having either a low or high risk of bias), or inconsistent findings in multiple RCTs.

4) No available evidence; no published RCTs that have assessed for interventional effect.

\section{Results}

\section{Literature Search}

Our electronic search resulted in 5142 potentially relevant articles. After reviewing titles and abstracts 24 potentially relevant articles remained. Of these, 12 articles met our inclusion criteria after reviewing the full text. A further 2 relevant articles were retrieved after checking the reference lists of included studies. Hence a total of 14 articles were included in this review. The search strategy and results are presented in Figure 1.

\section{Assessment of Bias}

Figure 2 presents the overall assessment of the risk of bias. The assessment of the risk of bias for the individual studies is presented in Table 1 . Thirteen of the studies were assessed as having high risk of bias, whilst only one was deemed to be of low risk. The most prevalent shortcomings were found in the items relating to blinding (patient, care provider, outcome assessor), allocation concealment, randomisation, and the acceptability of compliance rates.

\section{Description of Included Studies}

Tables 2, 3, 4, 5, 6, 7, 8 and 9 present the characteristics of the included studies. Neuromuscular training in the included studies consisted of a wide variety of proprioceptive and strength training drills. Some studies also implemented protocols combining both interventions. 


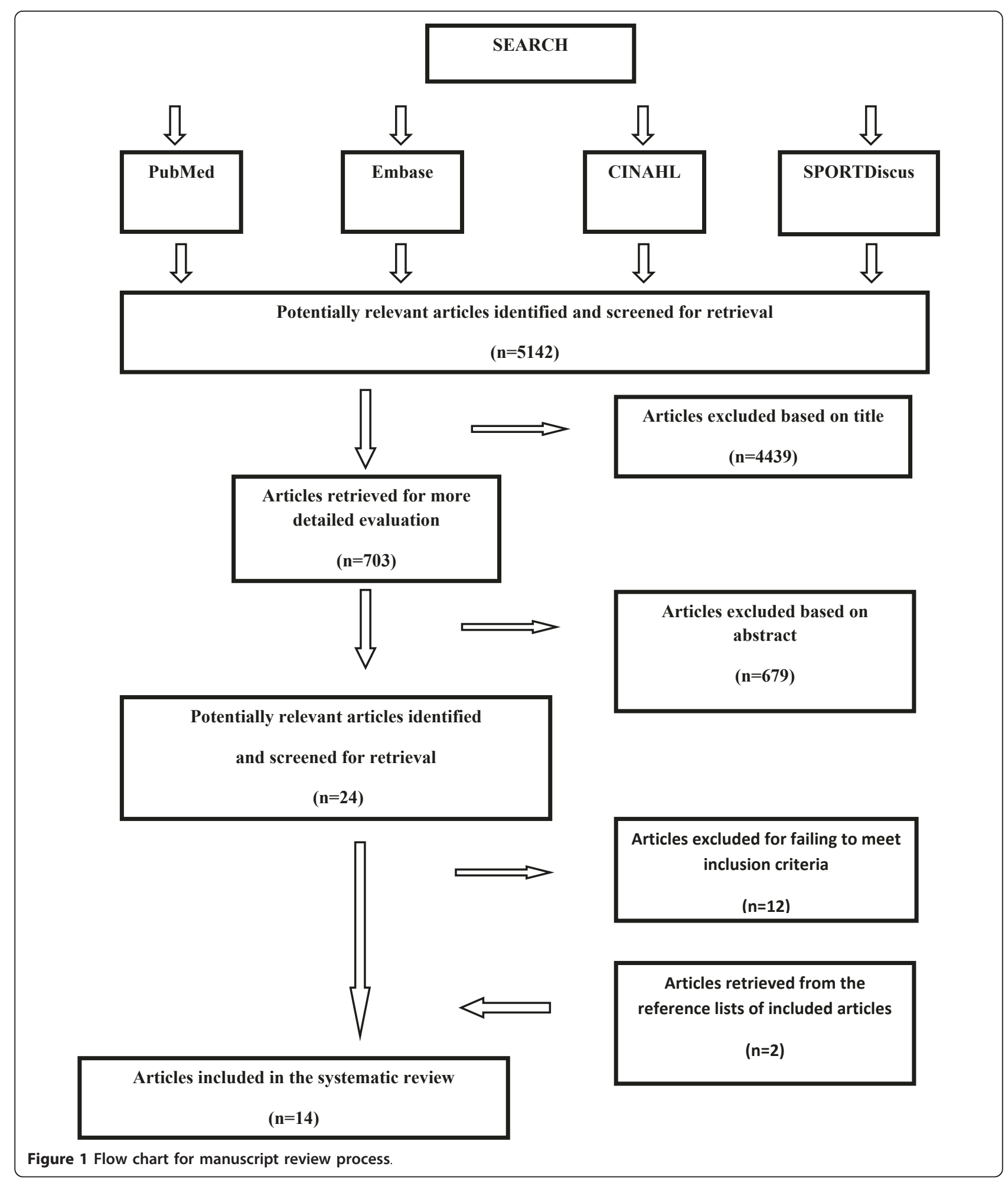






Table 1 Results of the risk of bias (+ = yes; - = no; ? = unsure)

\begin{tabular}{|c|c|c|c|c|c|c|c|c|c|c|c|c|}
\hline & & 1 & 2 & 3 & 4 & 5 & 6 & 7 & 8 & 9 & 10 & 11 \\
\hline 1. & Bernier \& Perrin, 1998 [20] & $?$ & $?$ & - & $?$ & $?$ & + & $?$ & + & $?$ & $?$ & + \\
\hline 2 & Docherty et al, 1998 [29] & $?$ & $?$ & - & $?$ & $?$ & - & $?$ & + & + & $?$ & $?$ \\
\hline 3. & Rozzi et al, 1999 [21] & - & - & - & $?$ & $?$ & $?$ & $?$ & + & $?$ & $?$ & \\
\hline 4. & Matsu & $?$ & $?$ & - & - & $?$ & $?$ & $?$ & + & $?$ & $?$ & + \\
\hline 5. & $\begin{array}{l}\text { Eils \& Rosenbaum, } 2001 \\
\text { [22] }\end{array}$ & $?$ & $?$ & - & $?$ & $?$ & $?$ & $?$ & + & $?$ & $?$ & + \\
\hline 6. & Kaminski et al, 2003 [32] & $?$ & $?$ & - & $?$ & $?$ & - & $?$ & + & $?$ & $?$ & ! \\
\hline 7. & Powers et al, 2004 [23] & $?$ & $?$ & - & - & + & - & $?$ & $?$ & $?$ & $?$ & $\uparrow$ \\
\hline . & 2005 [31] & $?$ & $?$ & - & - & $?$ & - & $?$ & + & $?$ & $?$ & + \\
\hline 9 & Kynsburg e & - & $?$ & - & $?$ & $?$ & - & $?$ & + & $?$ & $?$ & + \\
\hline 10 & Ross et al, 2007 [10] & $?$ & $?$ & - & $?$ & $?$ & - & $?$ & + & $?$ & $?$ & ? \\
\hline 11. & Hale et al, 2007 [7] & $?$ & $?$ & - & - & $?$ & + & $?$ & + & $?$ & $?$ & + \\
\hline 12 & McKeon et al, 2008 [8] & + & + & - & $?$ & $?$ & - & $?$ & + & $?$ & $?$ & + \\
\hline 13 & McKeon & + & + & - & - & - & + & + & + & + & $?$ & + \\
\hline 14 & Han e & $?$ & $?$ & - & - & $?$ & + & + & + & $?$ & $?$ & \\
\hline
\end{tabular}

The included studies were considered too heterogeneous to perform a meta-analysis. Therefore, we refrained from pooling and performed a best evidence synthesis. Furthermore, the contrasting nature of the various types of proprioceptive and strength training made it impossible to execute an analysis grouped by type of intervention. For that reason, we described the results of the main comparisons per outcome measure. Tables 10, 11, 12 and 13 present the results of the studies per outcome measure.

\section{Effectiveness of Neuromuscular Training Static Postural Stability}

Static postural stability impairments have frequently been associated with CAI [15-17], and have predicted ankle sprain injury in physically active individuals $[18,19]$. Hence, the assessment of static postural stability in single leg stance (SLS) is one method of determining, the efferent, or muscular response to afferent stimulation.

Nine studies described static postural stability as an outcome measure, all of which had a high risk of bias [6-8,10,20-24]. Static postural stability was measured 


\section{Table 2 Characteristics of the included studies}

\begin{tabular}{|c|c|c|c|c|c|c|c|}
\hline Author & $\begin{array}{c}\text { Study } \\
\text { Population }\end{array}$ & $\begin{array}{l}\text { Presence } \\
\text { of MI }\end{array}$ & Groupings/Intervention & Outcome Measures & Significant Findings & $\begin{array}{l}\text { Within Group Effect } \\
\text { Sizes }\end{array}$ & $\begin{array}{l}\text { Between Group Effect } \\
\text { Sizes }\end{array}$ \\
\hline $\begin{array}{c}\text { Bernier \& } \\
\text { Perrin, } \\
1998 \text { [20] }\end{array}$ & $\begin{array}{c}48 \text { males \& } \\
\text { females with } \\
\text { FAl }\end{array}$ & $\begin{array}{c}\text { Not } \\
\text { specified }\end{array}$ & $\begin{array}{c}\text { Control group }(n=14) \text { - no } \\
\text { intervention } \\
\text { Sham electrical stimulation } \\
\text { group }(n=14) \\
\text { Training group }(n=17) \text { - } \\
\text { static \& dynamic balance } \\
\text { training } 3 \text { times a week } \times 6 \\
\text { weeks }\end{array}$ & $\begin{array}{c}\text { SI \& MES in SLS for } 4 \text { conditions: } \\
\text { stable platform with eyes open } \\
\text { and eyes closed, and dynamic } \\
\text { platform with eyes open and } \\
\text { eyes closed } \\
\text { Active and passive JPS data for } 7 \\
\text { positions: } \\
15^{\circ} \text { inversion, } 0^{\circ} \text { degrees neutral, } \\
\text { and } 10^{\circ} \text { of eversion, performed at } \\
0^{\circ} \text { and } 25^{\circ} \text { of plantarflexion. } \\
\text { Maximum inversion in } 25^{\circ} \\
\text { plantarflexion was also assessed }\end{array}$ & $\begin{array}{c}\text { Training group showed significant MES } \\
\text { improvements over the other } 2 \text { groups } \\
\text { in AP \& ML directions for the stable } \\
\text { platform and dynamic platform } \\
\text { conditions respectively with eyes closed } \\
\text { Significant within training group } \\
\text { improvements were also noted in the A/ } \\
\text { P and M/L directions for both conditions } \\
\text { with eyes closed }\end{array}$ & $\begin{array}{l}\text { MES - stable platform, } \\
\text { eyes closed: } \\
\text { A/P direction: } 1.08 ; \\
\text { 95\% Cl (10.52-30.48) } \\
\text { M/L direction: } 1.09 ; \\
\text { 95\% Cl (5.28-25.72) } \\
\text { MES - dynamic } \\
\text { platform, eyes closed: } \\
\text { A/P direction: 0.71; } \\
\text { 95\% Cl (68.27-78.73) } \\
\text { M/L direction: } 0.958 ; \\
\text { 95\% Cl (65.25-74.75) }\end{array}$ & $\begin{array}{c}\text { MES - stable platform, } \\
\text { eyes closed: } \\
\text { A/P direction: 0.99 } \\
95 \% \text { Cl (12.13-31.87) } \\
\text { M/L direction: 0.92; 95\% } \\
\text { Cl (12.63-33.37) } \\
\text { MES - dynamic platform, } \\
\text { eyes closed: } \\
\text { A/P direction: } 0.52 ; 95 \% \\
\text { Cl } \\
\text { (63.9-81.10) } \\
\text { M/L direction: } 0.55 ; 95 \% \\
\text { Cl } \\
\text { (60.9-78.1) }\end{array}$ \\
\hline $\begin{array}{l}\text { Docherty } \\
\text { et al, } \\
1998 \text { [29] }\end{array}$ & $\begin{array}{l}20 \text { healthy } \\
\text { college } \\
\text { students (10 } \\
\text { males, } 10 \\
\text { females) } \\
\text { with FAl }\end{array}$ & $\begin{array}{c}\text { Not } \\
\text { specified }\end{array}$ & $\begin{array}{l}\text { Training group }(n=10)-T- \\
\text { band strengthening } 3 \text { times } \\
\text { a week } \times 6 \text { weeks } \\
\text { Control group }(n=10) \text { - no } \\
\text { intervention }\end{array}$ & $\begin{array}{c}\text { Dorsiflexor and evertor isometric } \\
\text { muscle strengths } \\
\text { Active JPS data collected at } 20^{\circ} \\
\text { for inversion \& plantarflexion, \& } \\
\text { at } 10^{\circ} \text { for eversion and } \\
\text { dorsiflexion }\end{array}$ & $\begin{array}{c}\text { Significant beween group interactions } \\
\text { for dorisflexion and eversion strength, } \\
\text { and inversion, and plantarflexion JPS } \\
\text { Significant improvements in all strength } \\
\text { and JPS measures post-test within the } \\
\text { training group }\end{array}$ & $\begin{array}{c}\text { Dorsiflexion strength: } \\
\text { 2.99; 95\% Cl (38.51- } \\
45.39) \\
\text { Eversion strength: } \\
\text { 0.83; 95\% Cl (34.42- } \\
41.48) \\
\text { Inversion JPS: 0.98; } \\
\text { 95\% CI (2.38-7.22) } \\
\text { Eversion JPS: 0.77; } \\
\text { 95\% Cl (1.55-5.15) } \\
\text { Dorsiflexion JPS: 0.85; } \\
\text { 95\% Cl (1.56-4.54) } \\
\text { Plantarflexion JPS: 1.51; } \\
\text { 95\% Cl (2.51-6.79) }\end{array}$ & $\begin{array}{l}\text { Dorsiflexion strength: } \\
\text { 2.93; } \\
\text { 95\% Cl (39.31-45.19) } \\
\text { Eversion strength: 1.94; } \\
\text { 95\% Cl (27.77-44.93) } \\
\text { Inversion JPS: 1.32; 95\% } \\
\text { Cl (2.92-6.28) } \\
\text { Plantarflexion JPS: } 1.56 ; \\
\text { 95\% Cl (2.06-4.84) }\end{array}$ \\
\hline
\end{tabular}

$\mathrm{MI}=$ mechanical instability; $\mathrm{FAI}=$ functional ankle instability, $\mathrm{SI}=$ stability index, $\mathrm{MES}=$ modified equilibrium score, JPS $=$ joint position sense, $\mathrm{A} / \mathrm{P}=$ anterior-posterior, $\mathrm{M} / \mathrm{L}=$ medial/lateral 
Table 3 Characteristics of the included studies (continued)

\begin{tabular}{|c|c|c|c|c|c|c|c|}
\hline Author & Study Population & $\begin{array}{l}\text { Presence } \\
\text { of } \mathrm{MI}\end{array}$ & Groupings/Intervention & Outcome Measures & Significant Findings & $\begin{array}{l}\text { Within Group Effect } \\
\text { Sizes }\end{array}$ & $\begin{array}{c}\text { Between Group Effect } \\
\text { Sizes }\end{array}$ \\
\hline $\begin{array}{l}\text { Rozzi et al, } \\
1999 \text { [21] }\end{array}$ & $\begin{array}{c}26 \text { active university } \\
\text { students (15 male, } 11 \\
\text { female) with and without } \\
\text { FAl }\end{array}$ & Not specified & $\begin{array}{c}\text { Training group }(n=13) \text { - } \\
\text { unilateral static and } \\
\text { dynamic Biodex stability } \\
\text { training } 3 \text { times a week } \times \\
4 \text { weeks } \\
\text { Healthy control group } \\
(n=13) \text { - identical training } \\
\text { to the FAl group }\end{array}$ & $\begin{array}{l}\text { Biodex generated Sls, } \\
\text { recorded for } 4 \text { conditions: } \\
\text { involved limb at levels } 2 \\
\text { and 6, and uninvolved } \\
\text { limb at levels } 2 \text { and } 6 \\
\text { AJFAT scores. }\end{array}$ & $\begin{array}{c}\text { Subjects in both groups } \\
\text { demonstrated significant post- } \\
\text { training improvements in } \\
\text { balance ability at stability } \\
\text { levels } 2 \text { and } 6 \\
\text { Post-training AJFAT scores } \\
\text { were significantly better for } \\
\text { both groups }\end{array}$ & $\begin{array}{l}\text { SI at level 2: 1.13; } \\
\text { 95\% CI (2.25-6.31) } \\
\text { SI at level 6: 0.73; } \\
\text { 95\% CI (1.09-2.47) } \\
\text { AJFAT Scores: } 2.39 ; \\
\text { 95\% CI (19.47-23.41) }\end{array}$ & $\begin{array}{l}\text { No significant between } \\
\text { group effect for SI at } \\
\text { level } 2 \text { or } 6 \text { \& AJFAT }\end{array}$ \\
\hline $\begin{array}{l}\text { Matsusaka } \\
\text { et al, } 2001 \\
{[6]}\end{array}$ & $\begin{array}{c}22 \text { university students (10 } \\
\text { women, } 12 \text { men) with } \\
\text { unilateral FAl }\end{array}$ & $\begin{array}{l}\text { Present in } 73 \% \\
\text { of subjects, as } \\
\text { evidenced by a } \\
\text { +ve anterior } \\
\text { drawer sign }\end{array}$ & $\begin{array}{c}\text { Tape and exercise group } \\
(\mathrm{n}=11,7 \text { with } \mathrm{MI}) \text { - ankle } \\
\text { disc training } 5 \text { times per } \\
\text { week } \times 10 \text { weeks with } \\
\text { ankle tape in situ } \\
\text { Exercise only group } \\
(\mathrm{n}=11,9 \text { with } \mathrm{MI}) \text { - } \\
\text { identical programme } \\
\text { without ankle tape in situ } \\
\text { Healthy adult group } \\
(\mathrm{n}=21) \text {-tested once to } \\
\text { determine normal range of } \\
\text { rectangular area values }\end{array}$ & $\begin{array}{l}\text { Postural sway was } \\
\text { quantified using } \\
\text { rectangular area values } \\
\text { taken pretest and at } \\
2,3,4,5,6,8 \text {, and } 10 \text { weeks of } \\
\text { training }\end{array}$ & $\begin{array}{c}\text { In the exercise only group } \\
\text { postural sway values improved } \\
\text { significantly after } 6 \text { weeks and } \\
\text { were within the normal range } \\
\text { after } 8 \text { weeks }\end{array}$ & $\begin{array}{c}\text { Exercise only group: } \\
\text { Rectangular area } \\
\text { values at } 6 \text { weeks: } \\
1.501 \\
12.2-15.5 \\
\text { Rectangular area } \\
\text { values at } 8 \text { weeks: } \\
1.921 \\
11.6-14\end{array}$ & $\begin{array}{c}\text { No significant between } \\
\text { group effect at } 6 \& 8 \\
\text { weeks }\end{array}$ \\
\hline
\end{tabular}


Table 4 Characteristics of the included studies (continued)

\begin{tabular}{|c|c|c|c|c|c|c|c|}
\hline Author & Study Population & $\begin{array}{l}\text { Presence } \\
\text { of MI }\end{array}$ & $\begin{array}{l}\text { Groupings/ } \\
\text { Intervention }\end{array}$ & Outcome Measures & Significant Findings & $\begin{array}{l}\text { Within Group Effect } \\
\text { Sizes }\end{array}$ & $\begin{array}{l}\text { Between Group } \\
\text { Effect Sizes }\end{array}$ \\
\hline $\begin{array}{c}\text { Eils \& } \\
\text { Rosenbaum, } \\
2001[22]\end{array}$ & $\begin{array}{c}30 \text { subjects (18 male, } \\
12 \text { female) with } 48 \\
\text { unstable ankles }\end{array}$ & Not specified & $\begin{array}{c}\text { Training group }(\mathrm{n}= \\
20,31 \text { unstable ankles) } \\
\text { - multi-station } \\
\text { proprioceptive } \\
\text { exercises once per } \\
\text { week } \times 6 \text { weeks } \\
\text { Control group }(n=10, \\
17 \text { unstable ankles) - } \\
\text { no intervention }\end{array}$ & $\begin{array}{l}\text { Passive JPS was assessed } \\
\text { for } 10^{\circ} \text { and } 20^{\circ} \text { of } \\
\text { dorsiflexion, and } 15^{\circ} \text { and } \\
30^{\circ} \text { of plantarflexion } \\
\text { Postural Sway in } \mathrm{M} / \mathrm{L} \text { and } \\
\text { A/P directions as well as } \\
\text { sway distance was assessed } \\
\text { in } \mathrm{SLS} \\
\text { MRTs of TA, PL, and PB } \\
\text { following a sudden } \\
\text { inversion perturbation } \\
\text { Frequency of recurrence at } \\
\text { one year follow up }\end{array}$ & $\begin{array}{l}\text { In the exercise group the results } \\
\text { showed significant improvements in } \\
\text { JPS (except for } 10^{\circ} \text { of DF), postural } \\
\text { sway measures, as well as a } \\
\text { significant increase in MRTs for PL } \\
\text { and PB } \\
\text { A significant reduction in frequency } \\
\text { of ankle sprains at one year follow } \\
\text { up was also noted within the } \\
\text { exercise group }\end{array}$ & $\begin{array}{c}\text { JPS at } 20^{\circ} \text { DF: 0.71; } \\
\text { 95\% Cl (1.22-1.68) } \\
\text { JPS at 15 PF: 0.90; } \\
\text { 95\% Cl (1.6-2.2) } \\
\text { JPS at 30 PF: 0.86; } \\
\text { 95\% Cl (1.87-2.43) } \\
\text { Mean Error: 0.98; 95\% } \\
\text { Cl (1.57-1.93) } \\
\text { Postural Sway, std dev } \\
\text { M/L: 0.26; 95\% Cl } \\
\text { (4.14-4.66) } \\
\text { Postural Sway, max } \\
\text { sway M/L: 0.48; 95\% } \\
\text { Cl (20.01-22.69) } \\
\text { Postural Sway, total } \\
\text { Sway distance: 0.41; } \\
\text { 95\% Cl (423.66-498.64) } \\
\text { MRT of PL: 0.50; 95\% } \\
\text { CI (60.96-65.44) } \\
\text { MRT of PB: 0.54; 95\% } \\
\text { Cl (66.4-70.9) }\end{array}$ & $\begin{array}{c}\text { No significant } \\
\text { between group } \\
\text { difference was } \\
\text { observed }\end{array}$ \\
\hline $\begin{array}{l}\text { Kaminski et } \\
\text { al, } 2003 \text { [32] }\end{array}$ & $\begin{array}{c}38 \text { ( } 22 \text { men, } 16 \\
\text { women) subjects } \\
\text { with FAl }\end{array}$ & Not specified & $\begin{array}{c}\text { Strength training } \\
\text { group - T-band } \\
\text { strengthening of } \\
\text { invertors \& evertors } 3 \\
\text { times per week } \times 6 \\
\text { weeks } \\
\text { Proprioception training } \\
\text { group - "T-band kicks" } \\
3 \text { times per week × } 6 \\
\text { weeks } \\
\text { Coupled strength \& } \\
\text { proprioception group - } \\
\text { both exercise } \\
\text { protocols combined } \\
\text { Control group no } \\
\text { intervention }\end{array}$ & $\begin{array}{c}\text { Isokinetic strength } \\
\text { measures of average torque } \\
\text { and peak torque eversion } \\
\text { to inversion (E/I) ratios, } \\
\text { calculated at } 30 \% \mathrm{sec} \text { and } \\
120^{\circ} / \mathrm{sec}\end{array}$ & $\begin{array}{c}\text { No significant differences in average } \\
\text { torque or peak torque } E / I \text { ratios for } \\
\text { any of the groups }\end{array}$ & $\begin{array}{l}\text { No significant within } \\
\text { group effect was } \\
\text { observed }\end{array}$ & $\begin{array}{l}\text { No significant } \\
\text { between group } \\
\text { difference was } \\
\text { observed }\end{array}$ \\
\hline
\end{tabular}

$\mathrm{MI}=$ mechanical instability; FAI = functional ankle instability; JPS = joint position sense; $\mathrm{A} / \mathrm{P}=$ anterior-posterior; $\mathrm{M} / \mathrm{L}=$ medial/lateral; $\mathrm{SLS}=$ single leg stance; $\mathrm{MRT}=$ muscle reaction time; $\mathrm{TA}=$ tibialis anterior; $\mathrm{PL}=$ peroneus longus; $\mathrm{PB}=$ peroneus brevis 
Table 5 Characteristics of the included studies (continued)

\begin{tabular}{|c|c|c|c|c|c|c|c|}
\hline Author & $\begin{array}{c}\text { Study } \\
\text { Population }\end{array}$ & $\begin{array}{c}\text { Presence } \\
\text { of } \mathrm{MI}\end{array}$ & $\begin{array}{c}\text { Groupings/ } \\
\text { Intervention }\end{array}$ & Outcome Measures & Significant Findings & $\begin{array}{l}\text { Within Group } \\
\text { Effect Sizes }\end{array}$ & $\begin{array}{l}\text { Between } \\
\text { Group Effect } \\
\text { Sizes }\end{array}$ \\
\hline $\begin{array}{c}\text { Powers } \\
\text { et al, } \\
2004 \\
{[23]}\end{array}$ & $\begin{array}{l}38 \text { subjects } \\
\text { (22 males, } \\
16 \text { females) } \\
\text { with } \\
\text { unilateral } \\
\text { FAl }\end{array}$ & $\begin{array}{l}\text { Absent on } \\
\text { examination }\end{array}$ & $\begin{array}{c}\text { Strength training } \\
\text { group - theraband } \\
\text { strength training } 3 \\
\text { times a week } \times 6 \\
\text { weeks } \\
\text { Proprioceptive } \\
\text { training group } \\
\text {-proprioceptive } \\
\text { training involving "T- } \\
\text { band kicks" } 3 \text { times } \\
\text { a week } \times 6 \text { weeks } \\
\text { Combination } \\
\text { training group } \\
\text {-performed a } \\
\text { combination of both } \\
\text { training protocols } 3 \\
\text { times a week } \times 6 \\
\text { weeks } \\
\text { Control group - no } \\
\text { intervention }\end{array}$ & $\begin{array}{l}\text { Muscle fatigue was } \\
\text { determined using } \\
\text { the median power } \\
\text { frequency (fmed) } \\
\text { from an EMG signal } \\
\text { for TA and PL } \\
\text { COP values for A/P } \\
\text { and } M / L \text { directions, } \\
\text { and the mean } \\
\text { overall deviations } \\
\text { from COP were } \\
\text { obtained }\end{array}$ & $\begin{array}{l}\text { No significant effects of } \\
\text { any intervention on } \\
\text { measures of muscle fatigue } \\
\text { and static balance }\end{array}$ & $\begin{array}{l}\text { No significant } \\
\text { within group } \\
\text { effect was } \\
\text { observed }\end{array}$ & $\begin{array}{l}\text { No significant } \\
\text { effect between } \\
\text { group effect } \\
\text { was observed }\end{array}$ \\
\hline $\begin{array}{l}\text { Clarke } \\
\text { and } \\
\text { Burden, } \\
2005 \\
{[31]}\end{array}$ & $\begin{array}{l}19 \text { male } \\
\text { subjects } \\
\text { with FAl }\end{array}$ & $\begin{array}{l}\text { Absent on } \\
\text { examination }\end{array}$ & $\begin{array}{l}\text { Control group }(\mathrm{n}= \\
\text { 9) - no intervention } \\
\text { Exercise group }(\mathrm{n}= \\
\text { 10) - wobble board } \\
\text { training } 3 \text { times a } \\
\text { week } \times 4 \text { weeks }\end{array}$ & $\begin{array}{l}\text { MRTs were measured } \\
\text { for TA, and } P L \text { in } \\
\text { response to sudden } \\
\text { inversion } \\
\text { AJFAT scores }\end{array}$ & $\begin{array}{l}\text { The exercise group showed } \\
\text { a significant decrease in } \\
\text { muscle onset latency for } \\
\text { both TA and PL, and a } \\
\text { significant improvement in } \\
\text { AJFAT scores }\end{array}$ & $\begin{array}{c}\mathrm{TA}=1.29 \\
\mathrm{PL}=1.20 \\
\text { Both effect sizes } \\
\text { were reported in } \\
\text { the paper } \\
\text { without } \\
\text { presentation of } \\
\text { mean } \pm \mathrm{SD} \\
\text { values }\end{array}$ & $\begin{array}{c}\text { Data was } \\
\text { presented in } \\
\text { graphical } \\
\text { format without } \\
\text { the reporting of } \\
\text { mean } \pm S D \\
\text { values }\end{array}$ \\
\hline
\end{tabular}

$\mathrm{MI}=$ mechanical instability $; \mathrm{FAI}=$ functional ankle instability $; \mathrm{EMG}=$ electromyography, $\mathrm{TA}=$ tibialis anterior; $\mathrm{PL}=$ peroneus longus; $\mathrm{COP}=$ center of pressure; $\mathrm{A} /$ $\mathrm{P}=$ anterior-posterior; $\mathrm{M} / \mathrm{L}=$ medial/lateral; $\mathrm{MRT}=$ muscle reaction time; $\mathrm{AJFAT}=$ ankle joint functional assessment tool; $\mathrm{SD}=$ standard deviation

Table 6 Characteristics of the included studies (continued)

\begin{tabular}{|c|c|c|c|c|c|c|c|}
\hline Author & $\begin{array}{c}\text { Study } \\
\text { Population }\end{array}$ & $\begin{array}{c}\text { Presence } \\
\text { of } \mathrm{MI}\end{array}$ & $\begin{array}{l}\text { Groupings/ } \\
\text { Intervention }\end{array}$ & Outcome Measures & Significant Findings & $\begin{array}{c}\text { Within } \\
\text { Group } \\
\text { Effect } \\
\text { Sizes } \\
\end{array}$ & $\begin{array}{c}\text { Between } \\
\text { Group } \\
\text { Effect } \\
\text { Sizes } \\
\end{array}$ \\
\hline $\begin{array}{l}\text { Kynsburg } \\
\text { et al, } \\
2006[30]\end{array}$ & $\begin{array}{c}20 \text { subjects } \\
\text { (10 males, } \\
10 \\
\text { females):10 } \\
\text { with } \\
\text { unilateral } \\
\text { FAl, } 10 \\
\text { healthy } \\
\text { matched } \\
\text { controls }\end{array}$ & Not specified & $\begin{array}{c}\text { FAl training group } \\
(\mathrm{n}=10) \text {-single leg } \\
\text { proprioceptive } \\
\text { training } 3 \text { times } \\
\text { per week } \times 6 \\
\text { weeks } \\
\text { Healthy control } \\
\text { group }(n=10) \text { - } \\
\text { no intervention }\end{array}$ & $\begin{array}{c}\text { Active JPS was measured } \\
\text { using the slope-box test } \\
\text { for } 11 \text { different slope } \\
\text { amplitudes in } 4 \\
\text { directions (anterior, } \\
\text { posterior, lateral, and } \\
\text { medial). }\end{array}$ & $\begin{array}{l}\text { Within the training group } \\
\text { there was a significant } \\
\text { improvement in JPS error } \\
\text { in the posterior direction, } \\
\text { as well as an overall } \\
\text { improvement of the mean } \\
\text { absolute estimate error }\end{array}$ & $\begin{array}{l}\text { Posterior } \\
\text { JPS: } 0.47 ; \\
95 \% \mathrm{Cl} \\
(1.76-5.0) \\
\text { Cumulative } \\
\text { JPS: } 0.40 ; \\
95 \% \mathrm{Cl} \\
(1.99-5.43)\end{array}$ & $\begin{array}{c}\text { Insufficient } \\
\text { data } \\
\text { Control } \\
\text { group } \\
\text { mean } \pm \text { SD } \\
\text { values are } \\
\text { not } \\
\text { reported in } \\
\text { the paper }\end{array}$ \\
\hline $\begin{array}{l}\text { Ross et al, } \\
2007 \text { [10] }\end{array}$ & $\begin{array}{c}30 \text { subjects } \\
\text { (16 females, } \\
14 \text { males) } \\
\text { with FAl }\end{array}$ & $\begin{array}{l}\text { Majority of } \\
\text { subjects had Ml } \\
\text { (67\% with a } \\
\text { positive anterior } \\
\text { drawer, } 76 \% \\
\text { with talar tilt } \\
\text { laxity) }\end{array}$ & $\begin{array}{l}\text { Coordination } \\
\text { training group ( } n= \\
\text { 10) - single leg } \\
\text { coordination } \\
\text { training } 3 \text { times a } \\
\text { week } \times 6 \text { weeks } \\
\text { SR coordination } \\
\text { training group ( } n= \\
\text { 10) - identical } \\
\text { exercises but } \\
\text { received SR } \\
\text { stimulation during } \\
\text { training } \\
\text { Control group ( } n= \\
\text { 10) - no } \\
\text { intervention }\end{array}$ & $\begin{array}{l}\text { COP measures: A/P sway } \\
\text { velocity, } M / L \text { sway } \\
\text { velocity, } M / L \text { standard } \\
\text { deviation, } M / L \text { maximum } \\
\text { excursion, and area }\end{array}$ & $\begin{array}{l}\text { The control and } \\
\text { coordination group } \\
\text { posttest outcomes were } \\
\text { not significantly different } \\
\text { for any of the measures } \\
\text { recorded }\end{array}$ & $\begin{array}{l}\text { No } \\
\text { significant } \\
\text { within } \\
\text { group } \\
\text { effect was } \\
\text { observed }\end{array}$ & $\begin{array}{l}\text { No } \\
\text { significant } \\
\text { effect } \\
\text { between } \\
\text { group } \\
\text { effect was } \\
\text { observed }\end{array}$ \\
\hline
\end{tabular}


Table 7 Characteristics of the included studies (continued)

\begin{tabular}{|c|c|c|c|c|c|c|c|}
\hline Author & $\begin{array}{c}\text { Study } \\
\text { Population }\end{array}$ & $\begin{array}{c}\text { Presence } \\
\text { of } \mathrm{MI}\end{array}$ & Groupings/Intervention & $\begin{array}{l}\text { Outcome } \\
\text { Measures }\end{array}$ & Significant Findings & $\begin{array}{l}\text { Within Group } \\
\text { Effect Sizes }\end{array}$ & $\begin{array}{c}\text { Between } \\
\text { Group Effect } \\
\text { Sizes }\end{array}$ \\
\hline $\begin{array}{l}\text { Hale } \\
\text { et al, } \\
2007 \\
{[7]}\end{array}$ & $\begin{array}{l}48 \text { subjects } \\
\text { (28 females, } \\
20 \text { males), } \\
29 \text { with CAl } \\
\text { and } 19 \\
\text { healthy } \\
\text { controls }\end{array}$ & $\begin{array}{c}\text { Not } \\
\text { specified }\end{array}$ & $\begin{array}{l}\text { FAl training group }(\mathrm{n}= \\
\text { 16) - } 4 \text { weeks of training } \\
\text { which addressed ROM, } \\
\text { strength, neuromuscular } \\
\text { control, and functional } \\
\text { tasks. Subjects visited the } \\
\text { lab on } 6 \text { occasions over } \\
\text { the } 4 \text { weeks, and } \\
\text { exercised } 5 \text { times per } \\
\text { week at home } \\
\text { FAl control group } \\
(n=13) \text { - no intervention } \\
\text { Healthy control group } \\
(\mathrm{n}=19) \text { - no intervention }\end{array}$ & $\begin{array}{l}\text { COP velocity in SLS } \\
\text { with eyes open } \\
\text { and closed } \\
\text { SEBT measures } \\
\text { taken in all } 8 \\
\text { directions } \\
\text { FADI and FADI- } \\
\text { Sport scores }\end{array}$ & $\begin{array}{l}\text { Following rehabilitation, } \\
\text { the FAl group had } \\
\text { significantly greater SEBT } \\
\text { reach improvements on } \\
\text { the involved limb than } \\
\text { the other two groups in } \\
\text { the posteromedial, } \\
\text { posterolateral, and lateral } \\
\text { directions as well as the } \\
\text { mean of all } 8 \text { reach } \\
\text { directions. Similarly, the } \\
\text { CAl-rehab group showed } \\
\text { showed significant } \\
\text { improvements over the } \\
\text { CAl-control group, and } \\
\text { the healthy group, for } \\
\text { FADI and FADI-Sport } \\
\text { scores }\end{array}$ & $\begin{array}{c}\text { Pre to post-test } \\
\text { scores are presented } \\
\text { in the paper for the } \\
\text { CAl group as } \\
\text { follows (values are } \\
\text { presented as \% } \\
\text { change): } \\
\text { P/M: } 0.07 ; 95 \% \\
\text { CI }(0.02-0.12) \\
\text { L: 0.09; } 95 \% \\
\text { CI }(0.04-0.08) \\
\text { P/L: } 0.12 ; 95 \% \\
\text { CI }(0.06-0.18) \\
\text { FADI: 7.30; 95\% } \\
\text { CI (2.47-12.13) } \\
\text { FADI Sport: 11.10; } \\
95 \% \text { Cl (6.35-15.86) }\end{array}$ & $\begin{array}{c}\text { Insufficient } \\
\text { data was } \\
\text { presented for } \\
\text { the } \\
\text { calculation of } \\
\text { between } \\
\text { group effect } \\
\text { sizes }\end{array}$ \\
\hline
\end{tabular}

$\overline{\mathrm{MI}}=$ mechanical instability; $\mathrm{CAI}=$ chronic ankle instability; ROM = range of movement; COP = center of pressure; SEBT = Star Excursion Balance Test; FADI = foot and ankle disability index; $\mathrm{P} / \mathrm{M}=$ posterior-medial; $\mathrm{L}=$ lateral; $\mathrm{P} / \mathrm{L}=$ posterior-lateral

using a multitude of different measures thereby making comparisons between studies extremely difficult. Bernier and Perrin [20] looked at the effect of 6 weeks of static and dynamic postural stability training on sway index (SI) measures, and modified equilibrium scores (MES). Measures were taken for weight-bearing SLS under both static and dynamic conditions, with and without visual cues. Outcomes were obtained for both the anteroposterior (AP) and mediolateral (ML) directions. Based on this one high risk RCT there is limited evidence for both time and group effect for a number of static and dynamic MES scores post training, namely the stable platform AP, and dynamic platform ML conditions. For two other MES conditions, namely the stable platform ML, and dynamic platform AP conditions, there was limited evidence of time but not group effect following the intervention. This effect was only apparent whilst subjects were tested under the eyes closed condition. No such effect was evident under the eyes open test condition. Based on the same high risk RCT there is limited evidence of neither time nor group effect for neuromuscular training for any of the 8 different SI measurements (i.e. stable and dynamic platform conditions in the AP and ML directions, with and without visual cues), or the 4 other MES conditions (i.e. stable and dynamic platform conditions in the AP and ML directions, with eyes open).

Based on another high risk study [21], which investigated the effect of 6 weeks of theraband strengthening in various planes of talocrural and subtalar joint motion, there is limited evidence of both time and group effect for two Biodex Stability System generated stability indices obtained in SLS.
McKeon et al [8] assessed the effect of 4 weeks of postural stability training drills that emphasised dynamic stabilisation in SLS on a variety of centre of pressure (COP) excursion, and time-to- boundary (TTB) measures obtained in SLS. The COP measures included a 95\% confidence ellipse, velocity, range, and standard deviation (SD), and were ascertained for both the AP and ML directions with and without visual cues. The TTB measures included the absolute minimum TTB, mean of TTB minima, and SD of TTB minima, in both $\mathrm{AP}$ and ML directions with eyes open and eyes closed. Based on this single high risk RCT there is limited evidence for time and group improvements for COP velocity values in a ML direction under the eyes closed condition post training. There is also limited evidence of both time and group effects for a number of TTB measures including the absolute minimum TTBML, mean minimum TTBML, mean minimum TTBAP, and SD minimum TTBAP, all of which occurred under the eyes closed test condition. There was limited evidence of neither group nor time effect following neuromuscular training for any of the other COP or TTB measures evaluated. Based on another high risk RCT [22], which looked at the effect of 6 weeks of multi-station proprioceptive exercises on COP excursions, there is limited evidence to support a time effect for COP total measures with eyes open following training.

Based on three high risk RCTs $[6,8,10]$, there is conflicting evidence regarding improvements in time and group effect for COP area values assessed in SLS, with eyes closed following neuromuscular training. Matsusaka et al [6], and Ross et al [10] looked at the efficacy of single leg coordination training over 10 and 6 weeks 
Table 8 Characteristics of the included studies (continued)

\begin{tabular}{|c|c|c|c|c|c|c|c|}
\hline Author & $\begin{array}{c}\text { Study } \\
\text { Population }\end{array}$ & $\begin{array}{c}\text { Presence } \\
\text { of MI }\end{array}$ & $\begin{array}{l}\text { Groupings/ } \\
\text { Intervention }\end{array}$ & Outcome Measures & Significant Findings & $\begin{array}{l}\text { Within Group Effect } \\
\text { Sizes }\end{array}$ & $\begin{array}{l}\text { Between Group } \\
\text { Effect Sizes }\end{array}$ \\
\hline $\begin{array}{l}\text { McKeon } \\
\text { et al, } \\
2008 \text { [8] }\end{array}$ & $\begin{array}{c}31 \\
\text { physically } \\
\text { active } \\
\text { individuals } \\
\text { (12 males, } \\
19 \text { females) } \\
\text { with a } \\
\text { history of } \\
\text { FAl }\end{array}$ & $\begin{array}{c}\text { Not } \\
\text { specified }\end{array}$ & $\begin{array}{l}\text { CAl balance } \\
\text { training group } \\
(\mathrm{n}=16)- \\
\text { balance } \\
\text { training that } \\
\text { emphasised } \\
\text { dynamic } \\
\text { stabilisation in } \\
\text { SLS } 3 \text { times per } \\
\text { week } \times 4 \\
\text { weeks } \\
\text { CAl control } \\
\text { group ( } \mathrm{n}=15) \\
\text { - no } \\
\text { intervention }\end{array}$ & $\begin{array}{l}\text { FADI and FADI-Sport } \\
\text { scores } \\
\text { COP excursion } \\
\text { measures including a } \\
95 \% \text { confidence } \\
\text { ellipse, velocity, range } \\
\text { and SD } \\
\text { TTB measures } \\
\text { including the absolute } \\
\text { minimum TTB, mean } \\
\text { of TTB minima, and } \\
\text { SD of TTB minima in } \\
\text { the A/P and } M / L \\
\text { directions with eyes } \\
\text { open and closed } \\
\text { SEBT measures in the } \\
\text { A/P, P/M, and } P / L \\
\text { directions }\end{array}$ & $\begin{array}{l}\text { The balance training } \\
\text { group had significant } \\
\text { improvements in the } \\
\text { FADI and the FADI- } \\
\text { Sport scores, in the } \\
\text { magnitude and } \\
\text { variability of TTB } \\
\text { measures with eyes } \\
\text { closed, and in reach } \\
\text { distances in the } \\
\text { posteromedial and } \\
\text { posterolateral } \\
\text { directions of the SEBT. } \\
\text { Only one of the } \\
\text { summary COP-based } \\
\text { measures (velocity of } \\
\text { COPML, eyes closed) } \\
\text { significantly changed } \\
\text { after balance training }\end{array}$ & $\begin{array}{c}\text { FADI Scores: 0.98; } \\
\text { 95\% CI (86.35-92.85) } \\
\text { FADI-Sport Scores: } \\
\text { 1.25; 95\% Cl } \\
\text { (72.0-82.9) } \\
\text { Absolute Min TTB M/ } \\
\text { L eyes closed: 0.8; } \\
\text { 95\% Cl (0.48-0.56) } \\
\text { Mean Min TTB M/L } \\
\text { eyes closed: 0.6; 95\% } \\
\text { CI (1.77-2.23) } \\
\text { Mean min TTB A/P } \\
\text { eyes closed: 0.41; } \\
\text { 95\% Cl (4.93-6.43) } \\
\text { SD Min TTB A/P eyes } \\
\text { closed: 0.75; 95\% } \\
\text { CI (3.05-3.97) } \\
\text { Velocity of COP A/P } \\
\text { eyes open: 0.07; 95\% } \\
\text { Cl (0.64-0.84) } \\
\text { Velocity of COP M/L } \\
\text { eyes Closed: 0.52; } \\
\text { 95\% Cl (1.85-2.27) } \\
\text { SEBT P/M reach: 0.64; } \\
\text { 95\% CI (0.81-0.93) } \\
\text { SEBT P/L reach: 0.67; } \\
\text { 95\% Cl (0.76-0.88) }\end{array}$ & $\begin{array}{c}\text { FADI Scores: 0.68; } \\
\text { 95\% Cl } \\
\text { (82.13-92.97) } \\
\text { FADI-Sport Scores: } \\
1.63 ; 95 \% \mathrm{Cl} \\
\text { (70.09-81.21) } \\
\text { Absolute Min TTB M/L } \\
\text { eyes closed: 0.60; 95\% } \\
\text { CI (0.49-0.57) } \\
\text { Mean Min TTB M/L } \\
\text { eyes closed: } 0.54 ; 95 \% \\
\text { Cl (1.79-2.25) } \\
\text { MeanMinTTB A/P } \\
\text { eyes closed: } 0.32 ; 95 \% \\
\text { Cl (4.76-6.09) } \\
\text { SD Min TTB A/P eyes } \\
\text { Closed: 1.18; 95\% } \\
\text { Cl (3.02-3.86) } \\
\text { Velocity of COP A/P } \\
\text { eyes open: } 0.38 ; 95 \% \\
\text { Cl (0.66-0.8) } \\
\text { Velocity of COP M/L } \\
\text { eyes Closed: } 0.42 ; 95 \% \\
\text { CI (1.81-2.23) } \\
\text { SEBT P/M reach: 1.83; } \\
\text { 95\% CI (0.82-0.9) } \\
\text { SEBT P/L reach: 1.0; } \\
\text { 95\% CI (0.77-0.88) }\end{array}$ \\
\hline
\end{tabular}

$\mathrm{MI}=$ mechanical instability; CAI = chronic ankle instability; FADI = foot and ankle disability index; COP = center of pressure; TTB = time-to-boundary;

$\mathrm{SD}=$ standard deviation; $\mathrm{SEBT}=$ Star Excursion Balance Test; $\mathrm{A} / \mathrm{P}=$ anterior-posterior; $\mathrm{M} / \mathrm{L}=$ medial/lateral; $\mathrm{P} / \mathrm{M}=$ posterior-medial; $\mathrm{P} / \mathrm{L}=$ posterior-lateral;

Min = minimum

respectively, whilst McKeon et al [8] assesed the efficacy of 4 weeks of balance training that emphasised dynamic stabilisation in SLS. Based solely on the study by Ross et al [10], there is limited evidence of no effectiveness following training for time or group improvements in ML COP Max measures with eyes open. Based on two high risk RCTs [22,23], there is moderate evidence of no effectiveness for strength or proprioceptive training on COP ML and AP measures when assessed with eyes open. Based on two other high risk RCTs $[8,10]$ there is moderate evidence of no effect for both time and group conditions for ML COP velocity, or ML COP SD values when assessed with eyes open. Furthermore based on these two studies there is moderate evidence of no group effect for AP COP velocity measures, and conflicting evidence regarding time effect after training, when assessed with eyes open.

Based on one other high risk RCT [24] there is limited evidence of no effect for both time and group conditions for total distance travelled when assessed with eyes open.

\section{Dynamic Postural Stability}

Two high risk studies $[7,8]$ described dynamic postural stability as an outcome measure. Both studies utilised the Star Excurion Balance Test (SEBT). Deficits in dynamic balance, as measured by the SEBT, have consistently been demonstrated in those with CAI [25-27].

Hale et al [7] looked at between group differences for all 8 directions of the SEBT, whereas McKeon et al [8] analysed time and group effects in the anterior, posteromedial and posterolateral directions only. Based on these two studies there is moderate evidence of group effect for improvements in reach distance in the posteromedial and posterolateral directions of the SEBT following neuromuscular training. There is moderate evidence of no group effect in the anterior direction. Based solely on the study by McKeon et al [8], there is limited evidence of time effect in the posteromedial and posterolateral directions. Based on the study by Hale et al [7], there is limited evidence of group effect in the lateral direction, and for the mean of all 8 directions of the SEBT. There is limited evidence of no effectiveness, or no available evidence to support time or group effects for all other components of the SEBT.

\section{Joint Position Sense}

Another proprioceptive measure commonly used to assess for improvements post training in subjects with CAI is joint position sense (JPS). Mechanoreceptors are sensitive to pressure and tension caused by dynamic movement and static positions. Hence if mechanoreceptor function is 
Table 9 Characteristics of the included studies (continued)

\begin{tabular}{|c|c|c|c|c|c|c|c|}
\hline Author & Study Population & $\begin{array}{l}\text { Presence } \\
\text { of } \mathrm{MI}\end{array}$ & $\begin{array}{l}\text { Groupings/ } \\
\text { Intervention }\end{array}$ & $\begin{array}{l}\text { Outcome } \\
\text { Measures }\end{array}$ & $\begin{array}{l}\text { Significant } \\
\text { Findings }\end{array}$ & $\begin{array}{l}\text { Within Group } \\
\text { Effect Sizes }\end{array}$ & $\begin{array}{l}\text { Between Group } \\
\text { Effect Sizes }\end{array}$ \\
\hline $\begin{array}{c}\text { McKeon } \\
\text { et al, } \\
2009 \\
{[35]}\end{array}$ & $\begin{array}{c}31 \text { physically active } \\
\text { individuals ( } 12 \\
\text { males, } 19 \text { females) }\end{array}$ & $\begin{array}{c}\text { Not } \\
\text { specified }\end{array}$ & $\begin{array}{l}\text { CAl balance } \\
\text { group }(\mathrm{n}=17) \\
\text { - training } \\
\text { designed to } \\
\text { challenge } \\
\text { recovery of } \\
\text { single limb } \\
\text { balance } 3 \text { times } \\
\text { per week } \times 4 \\
\text { weeks } \\
\text { CAl control } \\
\text { group }(n=15) \\
\text { - no } \\
\text { intervention }\end{array}$ & $\begin{array}{l}\text { Kinematic } \\
\text { measures of } \\
\text { rearfoot inversion/ } \\
\text { eversion, shank } \\
\text { rotation, and the } \\
\text { coupling } \\
\text { relationship of } \\
\text { these two } \\
\text { segments } \\
\text { throughout the } \\
\text { gait cycle were } \\
\text { taken whilst } \\
\text { walking and } \\
\text { running }\end{array}$ & $\begin{array}{c}\text { A significant } \\
\text { decrease was } \\
\text { noted in the } \\
\text { shank/rearfoot } \\
\text { coupling variabilty } \\
\text { during walking as } \\
\text { measured by the } \\
\text { deviation phase } \\
\text { within the balance } \\
\text { training group, and } \\
\text { between the } \\
\text { balance training } \\
\text { group and the } \\
\text { control group at } \\
\text { post-test }\end{array}$ & $\begin{array}{c}\text { Shank/rearfoot } \\
\text { coupling: 0.62; 95\% } \\
\text { Cl (11.71-17.59) }\end{array}$ & $\begin{array}{c}\text { Shank/rearfoot } \\
\text { coupling: 0.59; 95\% } \\
\text { Cl (11.42-17.89) }\end{array}$ \\
\hline $\begin{array}{l}\text { Han } \\
\text { et al, } \\
2009 \\
{[24]}\end{array}$ & $\begin{array}{l}40 \text { subjects ( } 20 \\
\text { males, } 20 \text { females) }\end{array}$ & $\begin{array}{c}\text { Not } \\
\text { specified }\end{array}$ & $\begin{array}{c}\text { CAl exercise } \\
\text { group }(n=10) \\
\text { - resisted "T- } \\
\text { band kicks" } 3 \\
\text { times per week } \\
\times 4 \text { weeks } \\
\text { CAl control } \\
\text { group }(n=10) \\
\text { - no } \\
\text { intervention } \\
\text { Healthy normals } \\
\text { exercise group } \\
(n=10) \text { - } \\
\text { exercise } \\
\text { programme as } \\
\text { per CAl exercise } \\
\text { group } \\
\text { Healthy normals } \\
\text { control group } \\
(n=10) \text { - no } \\
\text { intervention }\end{array}$ & $\begin{array}{l}\text { TDT of the COP in } \\
\text { SLS at } 4 \text { and } 8 \\
\text { weeks }\end{array}$ & $\begin{array}{l}\text { Balance training } \\
\text { significantly } \\
\text { improved in } \\
\text { subjects with and } \\
\text { without a history } \\
\text { of FAl. } \\
\text { Furthermore, the } \\
\text { exercise } \\
\text { programme caused } \\
\text { a significant } \\
\text { improvement in } \\
\text { balance for the FAl } \\
\text { exercise group } \\
\text { when compared to } \\
\text { the FAl control } \\
\text { group and the } \\
\text { healthy normal } \\
\text { group }\end{array}$ & $\begin{array}{l}\text { Insufficient data } \\
\text { No mean } \pm \mathrm{SD} \text { data } \\
\text { presented for } \\
\text { calculation }\end{array}$ & $\begin{array}{l}\text { Insufficient data } \\
\text { No mean } \pm \text { SD data } \\
\text { presented for } \\
\text { calculation }\end{array}$ \\
\hline
\end{tabular}

$\mathrm{MI}=$ mechanical instability; CAI = chronic ankle instability; TDT = total distance travelled; COP = center of pressure; SLS = single leg stance; SD = standard deviation

disrupted as is the case in subjects with CAI this often presents as reduced acuity in sensing joint position thereby leading to increased joint position errors. Konradsen and Magnusson [28] reported that an inversion error greater than 7 degrees would equal a $5 \mathrm{~mm}$ drop of the lateral border of the foot, which would lead to a hyper-invered foot position at initial contact therefore increasing the potential for injury.

In total 4 high risk studies looked at JPS. Bernier and Perrin [20], and Docherty et al [29] looked at active JPS in non weight-bearing (NWB) following 6 weeks of balance training, and strength training respectively. Kynsburg et al [30] looked at active JPS in WB using the slope box method of analysis pre and post 6 weeks of proprioceptive training. NWB passive JPS was also analysed in 2 studies [20,21] following 6 weeks of proprioceptive training. Based on one high risk RCT [29] there is limited evidence of both time and group effects for significant improvements in joint acuity for 20 degrees inversion, 10 degrees dorsiflexion, and 20 degrees plantarflexion following neuromuscular training. Based on two studies $[20,29]$ there is conflicting evidence regarding time effect, and moderate evidence of no group effect for improvement in JPS for 10 degrees of eversion. Based on the study by Bernier and Perrin [20] there is limited evidence of neither time nor group effect for active or passive angle reproduction at 15 degrees inversion, 0 degrees of neutral, 10 degrees of eversion, the aforementioned angles repeated at 25 degrees of plantarflexion, or maximal inversion which was defined as minus 5 degrees from each individual's maximum inversion active range. There is limited evidence of time effect in the posterior and combined directions of active WB JPS based on the high risk study by Kynsburg et al [30]. Based on the same study there is limited evidence of no time effect in the anterior, medial and lateral directions. Group effects were not analysed in this study. Based on another high risk study [22] there is limited evidence of time effect improvements in angle reproduction for 10 and 20 degrees of 
Table 10 Results of studies per outcome

\begin{tabular}{|c|c|c|c|c|c|c|}
\hline OUTCOME & DESCRIPTION & STUDIES & $\begin{array}{c}\text { TIME } \\
\text { EFFECT }\end{array}$ & $\begin{array}{l}\text { GROUP } \\
\text { EFFECT }\end{array}$ & $\begin{array}{l}\text { BEST EVIDENCE } \\
\text { SYNTHESIS (TIME) }\end{array}$ & $\begin{array}{c}\text { BEST EVIDENCE } \\
\text { SYNTHESIS (GROUP) }\end{array}$ \\
\hline \multirow{42}{*}{$\begin{array}{l}\text { Static Postural } \\
\text { Stability }\end{array}$} & S.I. for 8 conditions & & & & & \\
\hline & Stable platform (E.O) AP & $1 \mathrm{HR}$ RCT & NO & NO & LENE & LENE \\
\hline & Stable platform (E.O) ML & $1 \mathrm{HR}$ RCT & NO & NO & LENE & LENE \\
\hline & Stable platform (E.C) AP & $1 \mathrm{HR}$ RCT & NO & NO & LENE & LENE \\
\hline & Stable platform (E.C) ML & $1 \mathrm{HR}$ RCT & NO & NO & LENE & LENE \\
\hline & Dynamic platform (E.O) AP & $1 \mathrm{HR}$ RCT & NO & NO & LENE & LENE \\
\hline & Dynamic platform (E.O) ML & $1 \mathrm{HR}$ RCT & NO & NO & LENE & LENE \\
\hline & Dynamic platform (E.C) AP & $1 \mathrm{HR} R C T$ & NO & NO & LENE & LENE \\
\hline & Dynamic platform (E.C) ML & $1 \mathrm{HR}$ RCT & NO & NO & LENE & LENE \\
\hline & MES for 8 conditions & & & & & \\
\hline & Stable platform (E.O) AP & $1 \mathrm{HR} R C T$ & NO & NO & LENE & LENE \\
\hline & Stable platform (E.O) ML & $1 \mathrm{HR} R C T$ & NO & NO & LENE & LENE \\
\hline & Stable platform (E.C) AP & $1 \mathrm{HR} R C T$ & YES & YES & LEOE & LEOE \\
\hline & Stable platform (E.C) ML & $1 \mathrm{HR} R C T$ & YES & NO & LEOE & LENE \\
\hline & Dynamic platform (E.O) AP & $1 \mathrm{HR}$ RCT & NO & NO & LENE & LENE \\
\hline & Dynamic platform (E.O) ML & $1 \mathrm{HR}$ RCT & NO & NO & LENE & LENE \\
\hline & Dynamic platform (E.C) AP & $1 \mathrm{HR} R C T$ & YES & NO & LEOE & LENE \\
\hline & Dynamic platform (E.C) ML & $1 \mathrm{HR}$ RCT & YES & YES & LEOE & LEOE \\
\hline & $\begin{array}{l}\text { Biodex Generated } \\
\text { Stability Indices }\end{array}$ & & & & & \\
\hline & Involved limb at level 2 & $1 \mathrm{HR}$ RCT & YES & YES & LEOE & LEOE \\
\hline & Involved limb at level 6 & $1 \mathrm{HR}$ RCT & YES & YES & LEOE & LEOE \\
\hline & COP Values & & & & & \\
\hline & COP Area (E.O) & 3 HR RCTS & $\begin{array}{l}\text { YES, NO, } \\
\text { NO }\end{array}$ & YES, NO, NO & CE & $C E$ \\
\hline & COP M/L (E.O) & 2 HR RCTS & $\mathrm{NO}, \mathrm{NO}$ & $\mathrm{NO}, \mathrm{NO}$ & MENE & MENE \\
\hline & COP A/P (E.O) & 2 HR RCTS & $\mathrm{NO}, \mathrm{NO}$ & $\mathrm{NO}, \mathrm{NO}$ & MENE & MENE \\
\hline & COP Total (E.O) & $1 \mathrm{HR}$ RCT & YES & N/A & LEOE & LEOE \\
\hline & A/P COP vel (E.O) & 2 HR RCTS & NO, YES & $\mathrm{NO}, \mathrm{NO}$ & CE & MENE \\
\hline & A/P COP vel (E.C) & $1 \mathrm{HR} R C T$ & NO & NO & LENE & LENE \\
\hline & M/L COP vel (E.O) & 2 HR RCTS & $\mathrm{NO}, \mathrm{NO}$ & $\mathrm{NO}, \mathrm{NO}$ & MENE & MENE \\
\hline & M/L COP vel (E.C) & $1 \mathrm{HR} R C T$ & YES & YES & LEOE & LEOE \\
\hline & A/P COP sd (E.O) & $1 \mathrm{HR} R C T$ & NO & NO & LENE & LENE \\
\hline & A/P COP sd (E.C) & $1 \mathrm{HR}$ RCT & NO & NO & LENE & LENE \\
\hline & M/L COP sd (E.O) & 2 HR RCTS & $\mathrm{NO}, \mathrm{NO}$ & $\mathrm{NO}, \mathrm{NO}$ & MENE & MENE \\
\hline & $M / L$ COP sd (E.C) & $1 \mathrm{HR}$ RCT & NO & NO & LENE & LENE \\
\hline & M/L COP Max (E.O) & $1 \mathrm{HR}$ RCT & NO & NO & LENE & LENE \\
\hline & COP Area (E.C) & $1 \mathrm{HR}$ RCT & NO & NO & LENE & LENE \\
\hline & Range of COP AP (E.O) & $1 \mathrm{HR} R C T$ & NO & NO & LENE & LENE \\
\hline & Range of COP AP (E.C) & $1 \mathrm{HR} R C T$ & NO & NO & LENE & LENE \\
\hline & Range of COP ML (E.O) & $1 \mathrm{HR} R C T$ & NO & NO & LENE & LENE \\
\hline & Range of COP ML (E.C) & $1 \mathrm{HR} R C T$ & NO & NO & LENE & LENE \\
\hline & COP vel (E.O) & $1 \mathrm{HR}$ RCT & N/A & NO & NAE & LENE \\
\hline & COP vel (E.C) & $1 \mathrm{HR} R C T$ & N/A & $\mathrm{NO}$ & NAE & LENE \\
\hline
\end{tabular}

E.0. = eyes open

E.C. $=$ eyes closed LEOE = limited evidence of effectiveness

HR RTC $=$ high risk randomised controlled trial

$\mathrm{CE}=$ conflicting evidence

LR RTC = low risk randomized controlled trial

MENE $=$ moderate evidence, no effectiveness

LENE = limited evidence, no effectiveness

$\mathrm{NAE}=$ no available evidence

S.I. = stability index 
Table 11 Results of studies per outcome

\begin{tabular}{|c|c|c|c|c|c|c|}
\hline OUTCOME & DESCRIPTION & STUDIES & $\begin{array}{c}\text { TIME } \\
\text { EFFECT }\end{array}$ & $\begin{array}{l}\text { GROUP } \\
\text { EFFECT } \\
\end{array}$ & $\begin{array}{c}\text { BEST EVIDENCE } \\
\text { SYNTHESIS (TIME) }\end{array}$ & $\begin{array}{c}\text { BEST EVIDENCE } \\
\text { SYNTHESIS (GROUP) }\end{array}$ \\
\hline \multirow[t]{15}{*}{$\begin{array}{l}\text { Static Postural } \\
\text { Stability (cont.) }\end{array}$} & $\begin{array}{l}\text { Time to Boundary } \\
\text { (TTB) Measures: }\end{array}$ & & & & & \\
\hline & Abs. Min TTBML (E.O) & $1 \mathrm{HR} R C T$ & NO & NO & LENE & LENE \\
\hline & Abs. Min TTBML (E.C) & $1 \mathrm{HR} R C T$ & YES & YES & LEOE & LENE \\
\hline & Abs. Min TTBAP (E.O) & $1 \mathrm{HR} R C T$ & NO & NO & LENE & LENE \\
\hline & Abs. Min TTBAP (E.C) & $1 \mathrm{HR} R C T$ & NO & NO & LENE & LENE \\
\hline & Mean Min TTBML (E.O) & $1 \mathrm{HR} R C T$ & NO & NO & LENE & LENE \\
\hline & Mean Min TTBML (E.C) & $1 \mathrm{HR} R C T$ & YES & YES & LEOE & LENE \\
\hline & Mean Min TTBAP (E.O) & $1 \mathrm{HR} R C T$ & NO & NO & LENE & LENE \\
\hline & Mean Min TTBAP (E.C) & $1 \mathrm{HR} R C T$ & YES & YES & LEOE & LENE \\
\hline & SD Min TTBML (E.O) & $1 \mathrm{HR} R C T$ & NO & NO & LENE & LENE \\
\hline & SD Min TTBML (E.C) & $1 \mathrm{HR} R C T$ & NO & NO & LENE & LENE \\
\hline & SD Min TTBAP (E.O) & $1 \mathrm{HR} R C T$ & NO & NO & LENE & LENE \\
\hline & SD Min TTBAP (E.C) & $1 \mathrm{HR} R C T$ & YES & YES & LEOE & LENE \\
\hline & $\begin{array}{l}\text { Total Distance } \\
\text { Travelled Measure }\end{array}$ & & & & & \\
\hline & Involved limb & $1 \mathrm{HR} R C T$ & NO & NO & LENE & LENE \\
\hline \multirow{10}{*}{$\begin{array}{l}\text { Dynamic Postural } \\
\text { Stability }\end{array}$} & SEBT Measures & & & & & \\
\hline & Anterior & 2 HR RCTS & $\mathrm{N} / \mathrm{A}, \mathrm{NO}$ & $\mathrm{NO}, \mathrm{NO}$ & LENE & MENE \\
\hline & Posterior & $1 \mathrm{HR} R C T$ & N/A & NO & N/A & LENE \\
\hline & Lateral & $1 \mathrm{HR} R C T$ & N/A & YES & N/A & LEOE \\
\hline & Medial & $1 \mathrm{HR} R C T$ & N/A & NO & N/A & LENE \\
\hline & Anteromedial & $1 \mathrm{HR} R C T$ & N/A & NO & N/A & LENE \\
\hline & Anterolateral & $1 \mathrm{HR} R C T$ & N/A & NO & N/A & LENE \\
\hline & Posteromedial & $2 \mathrm{HR}$ RCTS & N/A, YES & YES, YES & LEOE & MENE \\
\hline & Posterolateral & $2 \mathrm{HR}$ RCTS & N/A, YES & YES, YES & LEOE & MENE \\
\hline & Mean of all 8 directions & $1 \mathrm{HR}$ RCT & N/A & YES & N/A & LEOE \\
\hline
\end{tabular}

Abs. Min = absolute minimum

Mean Min = mean minimum

SD Min = standard deviation of the minimum

TTBAP = time to boundary anteroposteriorly

$T \mathrm{TBML}=$ time to boundary mediolaterally

SEBT $=$ star excursion balance test

$\mathrm{HR} \mathrm{RCT}=$ high risk randomized controlled trial

LENE = limited evidence, no effectiveness

LEOE = limited evidence of effectiveness

MENE = moderate evidence, no effectiveness

E.0. $=$ eyes open E.C. $=$ eyes closed

dorsiflexion, as well as 15 and 30 degrees of plantarflexion. Again group effects were not calculated in this study.

\section{Muscle Onset Latencies}

Electromyography (EMG) has been used in the assessment of neuromuscular control as it allows the timing and degree of muscle activity to be determined during functional tasks. Two high risk studies $[22,31]$ looked at muscle onset latencies in response to a sudden inversion perturbation of the ankle joint. Based on the study by Eils and Rosenbaum [22] which looked at muscle reaction times (MRTs) in response to 30 degrees of sudden inversion perturbation there is limited evidence of a prolonged time effect for the peroneus longus (PL) and peroneus brevis (PB) MRTs following 6 weeks of proprioceptive training. Whilst this finding was at odds with the reduction in muscle onset latencies that was anticipated, the authors did however report on a more synchronised reaction of the PL and tibialis anterior (TA) in stabilising the ankle joint after sudden perturbation. Based on the same study there is limited evidence of no time effect improvement for TA onset post interevention. The authors failed to describe group effects. Based on the study by Clarke and Burden [31], which recorded MRTs in response to a sudden 20 degree inversion of the ankle via a trapdoor mechanism, there 
Table 12 Results of studies per outcome

\begin{tabular}{|c|c|c|c|c|c|c|}
\hline OUTCOME & DESCRIPTION & STUDIES & $\begin{array}{c}\text { TIME } \\
\text { EFFECT }\end{array}$ & $\begin{array}{l}\text { GROUP } \\
\text { EFFECT }\end{array}$ & $\begin{array}{l}\text { BEST EVIDENCE } \\
\text { SYNTHESIS (TIME) }\end{array}$ & $\begin{array}{c}\text { BEST EVIDENCE } \\
\text { SYNTHESIS (GROUP) }\end{array}$ \\
\hline \multirow{29}{*}{$\begin{array}{c}\text { Joint Position } \\
\text { Sense (JPS) }\end{array}$} & Active JPS (NWB) & & & & & \\
\hline & $15^{\circ}$ Inversion & $1 \mathrm{HR} R C T$ & NO & NO & LENE & LENE \\
\hline & $20^{\circ}$ Inversion & $1 \mathrm{HR}$ RCT & YES & YES & LEOE & LEOE \\
\hline & $\begin{array}{l}15^{\circ} \text { Inversion at } 25^{\circ} \\
\text { plantarflexion }\end{array}$ & $1 \mathrm{HR} R C T$ & NO & NO & LENE & LENE \\
\hline & Maximal Inversion & $1 \mathrm{HR} R C T$ & $\mathrm{NO}$ & NO & LENE & LENE \\
\hline & $10^{\circ}$ Eversion & $2 \mathrm{HR}$ RCTS & NO, YES & $\mathrm{NO}, \mathrm{NO}$ & CE & MENE \\
\hline & $\begin{array}{c}10^{\circ} \text { Eversion at } 25^{\circ} \\
\text { plantarflexion }\end{array}$ & $1 \mathrm{HR} R C T$ & NO & NO & LENE & LENE \\
\hline & $0^{\circ}$ Neutral & $1 \mathrm{HR} R C T$ & NO & NO & LENE & LENE \\
\hline & $\begin{array}{l}0^{\circ} \text { Neutral at } 25^{\circ} \\
\text { plantarflexion }\end{array}$ & $1 \mathrm{HR} R C T$ & NO & NO & LENE & LENE \\
\hline & $10^{\circ}$ Dorsiflexion & $1 \mathrm{HR} R C T$ & YES & YES & LEOE & LEOE \\
\hline & $20^{\circ}$ Plantarflexion & $1 \mathrm{HR} R C T$ & YES & YES & LEOE & LEOE \\
\hline & Active JPS (WB) & & & & & \\
\hline & Anterior & $1 \mathrm{HR} R C T$ & NO & N/A & LENE & NAE \\
\hline & Posterior & $1 \mathrm{HR}$ RCT & YES & N/A & LEOE & NAE \\
\hline & Lateral & $1 \mathrm{HR} R C T$ & NO & $\mathrm{N} / \mathrm{A}$ & LENE & NAE \\
\hline & Medial & $1 \mathrm{HR}$ RCT & NO & N/A & LENE & NAE \\
\hline & Overall & $1 \mathrm{HR} R C T$ & YES & N/A & LEOE & NAE \\
\hline & Passive JPS (NWB) & & & & & \\
\hline & $15^{\circ}$ Inversion & $1 \mathrm{HR} R C T$ & NO & NO & LENE & LENE \\
\hline & $\begin{array}{l}15^{\circ} \text { Inversion at } 25^{\circ} \\
\text { plantarflexion }\end{array}$ & $1 \mathrm{HR} R C T$ & NO & NO & LENE & LENE \\
\hline & Maximal Inversion & $1 \mathrm{HR}$ RCT & NO & NO & LENE & LENE \\
\hline & $10^{\circ}$ Eversion & $1 \mathrm{HR} R C T$ & NO & NO & LENE & LENE \\
\hline & $\begin{array}{l}10^{\circ} \text { Eversion at } 25^{\circ} \\
\text { plantarflexion }\end{array}$ & $1 \mathrm{HR} R C T$ & NO & NO & LENE & LENE \\
\hline & $0^{\circ}$ Neutral & $1 \mathrm{HR} R C T$ & NO & NO & LENE & LENE \\
\hline & $\begin{array}{l}0^{\circ} \text { Neutral at } 25^{\circ} \\
\text { plantarflexion }\end{array}$ & $1 \mathrm{HR}$ RCT & NO & NO & LENE & LENE \\
\hline & $10^{\circ}$ Dorsiflexion & $1 \mathrm{HR} R C T$ & YES & N/A & LEOE & NAE \\
\hline & $20^{\circ}$ Dorsiflexion & $1 \mathrm{HR} R C T$ & YES & N/A & LEOE & NAE \\
\hline & $15^{\circ}$ Plantarflexion & $1 \mathrm{HR} R C T$ & YES & N/A & LEOE & NAE \\
\hline & $30^{\circ}$ Plantarflexion & $1 \mathrm{HR}$ RCT & YES & N/A & LEOE & NAE \\
\hline
\end{tabular}

NWB $=$ non-weight bearing

WB $=$ weight-bearing

$\mathrm{HRRCT}=$ high risk randomised control trial

LENE = limited evidence, no effectiveness

LEOE $=$ limited evidence of effectiveness

$\mathrm{CE}=$ conflicting evidence

MENE = moderate evidence, no effectiveness

$\mathrm{NAE}=$ No available evidence

is limited evidence for time and group improvements for both TA and PL reaction times following 4 weeks of wobble board training.

\section{Strength}

Strength ratios have also been used to detect post training improvements in subjects with CAI. Two high risk studies looked at strength measures. Docherty et al [29] assessed isometric dorisflexor and evertor strengths using a handheld dynamometer after 6 weeks of resisted theraband exercises. Kaminski et al [32] looked at isokinetic eversion/inversion $(E / I)$ strength ratios after theraband strengthening, proprioceptive training incorporating "T-band kicks", and a combination of both protocols. This ratio expresses the viewpoint of the evertors acting concentrically to counteract the violent inversion mechanism in an open kinetic chain, and/or the invertors acting 
Table 13 Results of studies per outcome

\begin{tabular}{|c|c|c|c|c|c|c|}
\hline OUTCOME & DESCRIPTION & STUDIES & $\begin{array}{c}\text { TIME } \\
\text { EFFECT }\end{array}$ & $\begin{array}{l}\text { GROUP } \\
\text { EFFECT }\end{array}$ & $\begin{array}{l}\text { BEST EVIDENCE } \\
\text { SYNTHESIS (TIME) }\end{array}$ & $\begin{array}{c}\text { BEST EVIDENCE } \\
\text { SYNTHESIS (GROUP) }\end{array}$ \\
\hline \multirow[t]{6}{*}{ Muscle Onset Latencies } & $\begin{array}{l}\text { Muscle Reaction } \\
\text { Times }\end{array}$ & & & & & \\
\hline & $30^{\circ}$ Tilt TA & $1 \mathrm{HR} R C T$ & NO & N/A & LENE & NAE \\
\hline & $20^{\circ}$ Inversion TA & $1 \mathrm{HR}$ RCT & YES & N/A & LEOE & NAE \\
\hline & $30^{\circ}$ Tilt PL & $1 \mathrm{HR}$ RCT & YES & N/A & LEAE & NAE \\
\hline & $20^{\circ}$ Inversion PL & $1 \mathrm{HR}$ RCT & YES & N/A & LEOE & NAE \\
\hline & $30^{\circ}$ Tilt PB & $1 \mathrm{HR} R C T$ & YES & N/A & LEAE & NAE \\
\hline \multirow[t]{7}{*}{ Strength } & Isometric Strength & & & & & \\
\hline & $\begin{array}{l}\text { Isometric } \\
\text { Dorsiflexion }\end{array}$ & $1 \mathrm{HR}$ RCT & YES & YES & LEOE & LEOE \\
\hline & $\begin{array}{c}\text { Isometric Eversion } \\
\text { Isokinetic E/I } \\
\text { Ratios }\end{array}$ & $1 \mathrm{HR}$ RCT & YES & YES & LEOE & LEOE \\
\hline & $\begin{array}{c}\text { Average Torque at } \\
30^{\circ} / \mathrm{sec}\end{array}$ & $1 \mathrm{HR}$ RCT & NO & NO & LENE & LENE \\
\hline & $\begin{array}{c}\text { Peak Torque at } 30 \% \\
\text { sec }\end{array}$ & $1 \mathrm{HR}$ RCT & NO & NO & LENE & LENE \\
\hline & $\begin{array}{c}\text { Average Torque at } \\
120^{\circ} / \mathrm{sec}\end{array}$ & $1 \mathrm{HR}$ RCT & NO & NO & LENE & LENE \\
\hline & $\begin{array}{c}\text { Peak Torque at } \\
120^{\circ} / \mathrm{sec}\end{array}$ & $1 \mathrm{HR}$ RCT & NO & NO & LENE & LENE \\
\hline \multicolumn{7}{|l|}{ Muscle Fatigue } \\
\hline & $\begin{array}{l}\text { Median Power } \\
\text { Frequency TA }\end{array}$ & $1 \mathrm{HR}$ RCT & NO & NO & LENE & LENE \\
\hline \multicolumn{7}{|l|}{ Joint Kinematics } \\
\hline & Rearfoot Position & $1 \mathrm{LR} R C T$ & NO & NO & LENE & LENE \\
\hline & Shank Rotation & 1 LR RCT & NO & NO & LENE & LENE \\
\hline & $\begin{array}{l}\text { Shank/Rearfoot } \\
\text { Coupling }\end{array}$ & $1 \mathrm{LR} R C T$ & YES & YES & LEOE & LEOE \\
\hline \multicolumn{7}{|l|}{$\begin{array}{l}\text { Frequency of Injury } \\
\text { Recurrence }\end{array}$} \\
\hline & $\begin{array}{c}\text { Incidence at } 1 \text { year } \\
\text { follow up }\end{array}$ & 1 HR RCT & YES & N/A & LEOE & NAE \\
\hline \multicolumn{7}{|l|}{$\begin{array}{l}\text { Patient Perceived } \\
\text { Functional Stability }\end{array}$} \\
\hline & AJFAT & $2 \mathrm{HR}$ RCTS & YES, YES & YES, N/A & MEOE & LEOE \\
\hline & FADI & $2 \mathrm{HR}$ RCTS & N/A, YES & YES, YES & LEOE & MEOE \\
\hline & FADI-Sport & $2 \mathrm{HR}$ RCTS & N/A, YES & YES, YES & LEOE & MEOE \\
\hline
\end{tabular}

$\mathrm{TA}=$ tibialis anterior

$\mathrm{MEOE}=$ moderate evidence of effectiveness

$\mathrm{PL}=$ peroneus longus

AJFAT = ankle joint functional assessment tool

$\mathrm{PB}=$ peroneus brevis

$\mathrm{FADI}=$ foot and ankle disability index

LENE $=$ limited evidence, no effectiveness

$\mathrm{HR} R C T=$ high risk randomised controlled trial

LEOE $=$ limited evidence of effectiveness

LR RCT = low risk randomised controlled trial

MENE = moderate evidence, no effectiveness

$\mathrm{NAE}=$ no available evidence

LEAE $=$ limited evidence, adverse effect 
eccentrically to slow the lateral displacement of the tibia in a closed kinetic chain scenario. Based on the study by Docherty et al [29] there is limited evidence of both time and group effects for isometric dosiflexion and eversion strengths following this type of neuromuscular training. Based on the study by Kaminski et al [32] there is limited evidence of neither time nor group effect for average or peak torques calculated at 30 degrees/second and 120 degrees/second for any of the training groups.

\section{Muscle Fatigue}

It has been show that muscle fatigue can significantly impair postural control $[33,34]$. Thus, it is plausible that improvements in muscle strength and endurance through training would improve stability. One high risk RCT [23] looked at measures of median power frequency (fmed) from an EMG signal to assess for improvements in measures of muscle fatigue in the TA and PL following either resisted strength training, proprioceptive training, or a combination of both. Based on this study there is limited evidence of neither time nor group effect for improvements in measures of muscle fatigue for any of the training groups.

\section{Joint Kinematics}

One low risk RCT [35] looked at joint kinematics whilst walking and running on a threadmill. Kinematic measures of rearfoot inversion/eversion, shank rotation, and the coupling relationship between these two segments was analysed throughout the gait cycle whilst walking and running. Based solely on this study there is limited evidence of both time and group improvements for improved shank/rearfoot coupling variability during walking as measured by the deviation phase following 4 weeks of balance training. There is limited evidence of neither time nor group effectiveness for improvement in measures of rearfoot position, or shank rotation during walking or running. Equally there is limited evidence of no effect for time nor group improvements for shank/ rearfoot coupling whilst running following balance training.

\section{Frequency of Recurrence}

Incidence of recurrence at one year follow up was assessed by only one high risk RCT [22]. Based on this study there is limited evidence of time effect following the 6 week neuromuscular intervention. The authors did not report on group effects.

\section{Patient Perceived Stability}

Four high risk studies looked at patient perceived stability scales as an outcome measure. Two trials [21,31] utilised the Ankle Joint Functional Assessment Tool (AJFAT), to assess for the efficacy of 4 weeks of balance training. Two further studies $[7,8]$ used both the Foot and Ankle Disability Index (FADI), and it's sport's subsection the FADI-Sport to assess for the effectiveness of 4 weeks of balance training on patient perceived stability. The AJFAT is a 12 part questionnaire with the overall score calculated by totalling the point values from the 12 questions (maximum score $=48$ ). The higher the overall score the greater the perceived functional ability of the involved ankle. The FADI is another questionnaire used to quantify self reported disability in subjects with CAI. The FADI contains 26 items related to activities of daily living, and the FADI-Sport contains 8 items that evaluate perceived disability due to foot and ankle injury in endeavours associated with physical activity and sports participation.

Whilst the validity and reliablity of the AJFAT has yet to be established, the reliability and sensitivity of both components of the FADI have previously been reported in subjects with and without FAI [36]. The study by Clarke and Burden [31] looked at time effect only, whereas that of Hale et al [7] looked at group effects only. Hence based on the studies by Rozzi et al [21] and Clarke and Burden [31] there is moderate evidence of time effect improvement in AJFAT scores post neuromuscular training. Based solely on the study by Rozzi et al [21] there is limited evidence for group effect. Based on the studies by Hale et al [7], and McKeon et al [8] there is moderate evidence of group effect for improvements in both FADI and FADI-Sport scores respectively. Based purely on the study by McKeon et al [8] there is limited evidence of time effect for improvements in both the FADI and FADI-Sport scores.

\section{Discussion}

This review summarised the evidence for the effectiveness of neuromuscular training on a variety of sensorimotor and functional deficits in subjects with CAI. In general, this overview revealed only moderate or limited evidence in favour of neuromuscular training, according to outcome measures of static and dynamic postural stability, active and passive JPS, isometric strength, muscle onset latencies, shank-rearfoot coupling, patient perceived stability, and frequency of recurrence. However, for none of the outcome measures strong evidence in favour of neuromuscular training was found.

The aforementioned evidence is based on a limited number of studies $(\mathrm{n}=14)$, with a maximum of eight studies per outcome measure. In these studies neuromuscular training was defined as either proprioceptive drills, strength training, or a combination of both. However, the specific mechanisms of training were quite varible in terms of the mode, frequency, and the duration of the training period. Training protocols varied from 1 session per week for 6 weeks [22], to 5 times per week for 10 weeks [6]. In addition, heterogeneity among the studies was observed concering the study populations in terms of the presence or absence of concommitant MI, and outcome assessment. Furthermore, all but one of 
the studies included in the review were assessed as having a high risk of bias. Therefore, we refrained from statistical pooling of the results of the individual studies, and instead conducted a best evidence synthesis.

The assesment of risk of bias resulted in almost 93\% of the studies identified as having high risk. The threshold to differentiate between low and high risk of bias studies was based on the methodological study of van Tulder et al [14] in which they assessed the validity of the Cochrane Collaboration's tool for assessing the risk of bias in trials with back-pain interventions. In this study a threshold of $50 \%$ or less was associated with bias, therefore similar to van Rijn et al [12] it was decided that studies with 6 or more points were regarded as high risk studies. Critical items in the risk of bias assessment were items on randomisation (item 1 ), allocation concealment (item 2), and blinding (items 3,4 , and 5).

None of the studies scored positively on patient or care provider blinding, which is devoted to the fact that the setting of physical therapy often does not lend itself to the blinding of patients or care givers. All of the studies scored "unclear"on the item concerning compliance, and in $86 \%$ of the studies it was unclear whether or not co-interventions were avoided. Hence, these studies are more susceptible to selection bias, and as a consequence, the generalisability of the results in this review is adversely effected.

There are a number of plausible explanations to account for the variability in findings among certain studies, and the failure of others to produce statistically significant results. In the studies pertaining to static joint stability $[6-8,10,20-24]$ measures taken in the absence of visual cues tended to produce more meaningful results than those where visual input was retained. Vision is an extremely important sense for the control of balance. It is believed that even when somatosensory input is disrupted due to injury, visual information can provide an adequate amount of feedback to compensate for deficits in the central pathways or the vestibular system $[37,38]$. Hence, it was perhaps unsurprising that when this compensatory mechanism is removed through closing the eyes, deficits in the sensorimotor system become more apparent. This may be an important consideration for researchers to bear in mind when selecting outcome measures in the future.

Another possible reason for the inconsistent findings among studies is the lack of sensitivity of the measures chosen to detect post training improvements. Many of the studies in the review used traditional COP excursion values to assess for interventional efficacy [6-8,10,22-24]. Unfortunately, these measures have been shown not to be particularly sensitive in detecting CAI related postural control deficits, when compared to TTB measures
[17]. TTB measures have also been shown to be more sensitive than traditional COP excursion (COPE) measures in detecting post training improvement in subjects with FAI [8]. These findings may go some way towards explaining why COPE measures have failed to show significant post-training improvements in a number of the studies reviewed. In many of the other studies particularly those relating to strength and JPS $[20,22,29,30,32]$, failure to reveal significant post training effects may be best understood from a mode specificity standpoint, whereby the disparity between training protocols and the outcomes used to assess for efficacy appears to be too great. Researchers examining the area of CAI need to recognise that when subjects are trained using a specific protocol, outcomes that closely resemble the intervention are best suited to assess for treatment effect. Relating to the studies looking at muscle onset latencies $[22,31]$, differences in outcome can be accounted for to some degree due to the different algorithms used to calculate muscle onset latencies. Greater standardisation of testing protocols is required in order for meaningful comparisons to be made.

Furthermore, the majority of studies included in the review examined the efficacy of a specific treatment strategy such as balance training or strength training in isolation. Due to the multi-faceted nature of CAI which cannot be adequately explained through the dichotomy of MI and FI [5], a more comprehensive treatment approach combining strengthening, proprioceptive training, and functional retraining may be more effective in improving lower extremity function and preventing recurrent injury. Addressing local arthrokinematic impairments may also help elicit greater improvements for various outcomes. Following on from this, it may then be beneficial to develop a treatment or impairment based classification system that addresses the multi-factorial nature of the condition. Classification of individuals with CAI into different groups based on impairments or treatment response may lead to more efficient conservative management in the future.

Only one of the studies reviewed [22], looked at recurrence rates at one year follow-up. Hence there is certainly a need for more studies to examine interventional efficacy in the longer term. It is of paramount importance to know if immediate post-training improvements are maintained, and whether or not these improvements carry over to a long-term reduction in symptoms and prevention of injury recurrence. Further research is necessary before any meaningful conclusions can be drawn regarding the efficacy for neuromuscular training leading to improvements in joint kinematics and muscle fatigue. The findings to date relating to patient perceived functional stability look promising, though 
further reseach will be required to corroborate these preliminary results.

Although deemed to be outside the scope of this review a number of authors have advocated the use of adjuctive therapies such as taping and stochastic resonance stimulation combined with neuromuscular training. Preliminary findings indicate earlier and superior results than training alone $[6,10]$. Such additional interventions certainly warrant further investigation. Therapies providing a greater treatment effect than neuromuscular training alone may well have implications for improved function, a reduction in injury recurrence, and reduced treatment costs.

\section{Conclusion}

In conclusion, this review showed moderate or limited evidence of effectiveness in favour of neuromuscular training, according to the outcome measures of static and dynamic postural stability, active and passive JPS, isometric strength, muscle onset latencies, shank-rearfoot coupling and injury recurrence rates. For none of the outcome measures strong evidence of effectiveness was found. However, only a small number of studies [14] were eligible for inclusion in the review. Most studies were assessed as having a high risk of bias, and most studies were lacking power. Therefore we recommend conducting further high-quality RCTs with sufficient power to assess for the effectiveness of neuromuscular training in subjects with CAI. Such studies should also consider the importance of mode specificity of training, and the implementation of outcome measures with adequate sensitivity to detect interventional effect

\section{Additional material}

Additional file 1: Search terms. Search terms used for the identification of studies.

Additional file 2: Source of risk bias. Items used for the assessment of risk bias.

\footnotetext{
Author details

${ }^{1}$ Mount Carmel Hospital, Dublin, Ireland. ${ }^{2}$ School of Public Health, Physiotherapy and Population Science, University College Dublin, Dublin, Ireland. ${ }^{3}$ Institute for Sport and Health, University College Dublin, Dublin, Ireland.
}

\section{Authors' contributions}

JOD and ED conceived and performed the study and drafted the manuscript. All authors read and approved the final manuscript.

\section{Competing interests}

The authors declare that they have no competing interests.

Received: 17 February 2011 Accepted: 22 September 2011 Published: 22 September 2011
References

1. Fong DT, Hong Y, Chan LK, Yung PS, Chan KM: A systematic review on ankle injury and ankle sprain in sports. Sports Med 2007, 37:73-94.

2. Cooke MW, Lamb SE, Marsh J, Dale J: A survey of current consultant practice of treatment of severe ankle sprains in emergency departments in the United Kingdom. Emerg Med J 2003, 20:505-507.

3. de Bie RA, de Vet HC, van den Wildenberg FA, Lenssen T, Knipschild PG The prognosis of ankle sprains. Int J Sports Med 1997, 18:285-289.

4. Delahunt E, Coughlan GF, Caulfield B, Nightingale EJ, Lin CW, Hiller CE: Inclusion criteria when investigating insufficiencies in chronic ankle instability. Med Sci Sports Exerc 2010, 42:2106-2121.

5. Hertel J: Functional anatomy, pathomechanics and pathophysiology of lateral ankle instability. J Athl Train 2002, 37:364-375.

6. Matsusaka N, Yokoyama S, Tsurusaki T, Inokuchi S, Okita M: Effect of ankle disk training combined with tactile stimulation to the leg and foot on functional instability of the ankle. Am J Sports Med 2001, 29:25-30.

7. Hale SA, Hertel J, Olmsted-Kramer LC: The effect of a 4-week comprehensive rehabilitation program on postural control and lower extremity function in individuals with chronic ankle instability. J Orthop Sports Phys Ther 2007, 37:303-311

8. McKeon PO, Ingersoll CD, Kerrigan DC, Saliba E, Bennett BC, Hertel J: Balance training improves function and postural control in those with chronic ankle instability. Med Sci Sports Exerc 2008, 40:1810-1819.

9. Holmes A, Delahunt E: Treatment of common deficits associated with chronic ankle instability. Sports Med 2009, 39:207-224.

10. Ross SE, Arnold BL, Blackburn JT, Brown CN, Guskiewicz KM: Enhanced balance associated with coordination training with stochastic resonance stimulation in subjects with functional ankle instability: an experimental trial. J Neuroeng Rehabil 2007, 4:47.

11. Higgins JPT, Green S, (editors): Cochrane Handbook for Systematic Reviews of Interventions. Version 5.0.1 [updated September 2008]. The Cochrane Collaboration 2008 [http://www.cochrane-handbook.org].

12. van Rijn RM, van Ochten J, Luijsterburg PA, van Middelkoop M, Koes BW, Bierma-Zeinstra SM: Effectiveness of additional supervised exercises compared with conventional treatment alone in patients with acute lateral ankle sprains: systematic review. BMJ 2010, 341:c5688.

13. Cohen J: Statistical Power Analysis for the Behavioural Sciences. Hillsdale, NJ: Lawrence Erlbaum; 21988.

14. van Tulder MW, Esmail R, Bombardier C, Koes BW: Back schools for nonspecific low back pain. Cochrane Database Syst Rev 2000, , 2: CD000261.

15. Ross SE, Guskiewicz KM: Examination of static and dynamic postural stability in individuals with functionally stable and unstable ankles. Clin J sport Med 2004, 14:332-338.

16. Docherty $\mathrm{CL}$, Valovich McLeod TC, Shultz SJ: Postural control deficits in participants with functional ankle instability as measured by the balance error scoring system. Clin J Sport Med 2006, 16:203-208.

17. Hertel J, Olmsted-Kramer LC: Deficits in time-to-boundary measures of postural control with chronic ankle instability. Gait Posture 2007, 25:33-39.

18. Tropp H, Ekstrand J, Gillquist J: Stabilometry in functional instability of the ankle and its value in predicting injury. Med Sci Sports Exerc 1984, 16:64-66.

19. McGuine TA, Greene JJ, Best T, Leverson G: Balance as a predictor of ankle injuries in high school basketball players. Clin J Sport Med 2000 10:239-244.

20. Bernier JN, Perrin DH: Effect of coordination training on proprioception of the functionally unstable ankle. J Orthop Sports Phys Ther 1998, 27:264-275.

21. Rozzi SL, Lephart SM, Sterner R, Kuligowski L: Balance training for persons with functionally unstable ankles. J Orthop Sports Phys Ther 1999, 29:478-486.

22. Eils $E$, Rosenbaum D: A multi-station proprioceptive exercise program in patients with ankle instability. Med Sci Sports Exerc 2001, 33:1991-1998.

23. Powers ME, Buckley BD, Kaminski TW, Hubard TJ, Ortiz C: Six weeks of strength and proprioception training does not affect muscle fatigue and static balance in functional ankle instability. J Sport Rehabil 2004, 13:201-227.

24. Han K, Ricard MD, Fellingham GW: Effects of a 4-week exercise program on balance using elastic tubing as a perturbation force for individuals with a history of ankle sprains. J Orthop Sports Phys Ther 2009, 39:246-255. 
25. Gribble PA, Hertel J, Denegar CR, Buckley WE: The effects of fatigue and chronic ankle instability on dynamic postural control. J Athl Train 2004, 39:321-329.

26. Olmsted LC, Carcia CR, Hertel J, Shultz SJ: Efficacy of the star excursion balance tests in detecting reach deficits in subjects with chronic ankle instability. J Athl Train 2002, 37:501-506.

27. Hertel J, Braham RA, Hale SA, Olmsted-Kramer LC: Simplifying the star excursion balance test: analyses of subjects with and without chronic ankle instability. J Orthop Sports Phys Ther 2006, 36:131-137.

28. Konradsen L, Magnusson P: Increased inversion angle replication error in functional ankle instability. Knee Surg Sports Traumatol Arthrosc 2000, 8:246-251

29. Docherty $C L$, Moore JH, Arnold BL: Effects of strength training on strength development and joint position sense in functionally unstable ankles. J Athl Train 1998, 33:310-314.

30. Kynsburg A, Halasi T, Tállay A, Berkes I: Changes in joint position sense after conservatively treated chronic lateral ankle instability. Knee Surg Sports Traumatol Arthrosc 2006, 14:1299-1306.

31. Clark VM, Burden AM: A 4-week wobble board exercise programme improved muscle onset latency and perceived stability in individuals with a functionally unstable ankle. Phys Ther Sport 2005, 6:181-187.

32. Kaminski TW, Buckley BD, Powers ME, Hubbard TJ, Ortiz C: Effect of strength and proprioception training on eversion to inversion strength ratios in subjects with unilateral functional ankle instability. $\mathrm{Br} J$ Sports Med 2003, 37:410-415.

33. Vuillerme N, Danion F, Forestier N, Nougier V: Postural sway under muscle vibration and muscle fatigue in humans. Neurosci Lett 2002, 333:131-135.

34. Yaggie JA, McGregor SJ: Effects of isokinetic ankle fatigue on the maintenance of balance and postural limits. Arch Phys Med Rehabil 2002, 83:224-228.

35. McKeon PO, Paolini G, Ingersoll CD, Kerrigan DC, Saliba EN, Bennett BC, Hertel J: Effects of balance training on gait parameters in patients with chronic ankle instability: a randomized controlled trial. Clin Rehabil 2009, 23:609-621.

36. Hale SA, Hertel J: Reliability and sensitivity of the Foot and Ankle Disability Index in subjects with chronic ankle instability. J Athl Train 2005, 40:35-40

37. Dornan J, Fernie GR, Holliday PJ: Visual input: its importance in the control of postural sway. Arch Phys Med Rehabil 1978, 59:586-591.

38. Diener HC, Dichgans J, Guschlbauer B, Mau H: The significance of proprioception on postural stabilization as assessed by ischemia. Brain Res 1984, 296:103-109.

doi:10.1186/1758-2555-3-19

Cite this article as: O'Driscoll and Delahunt: Neuromuscular training to enhance sensorimotor and functional deficits in subjects with chronic ankle instability: A systematic review and best evidence synthesis. Sports Medicine, Arthroscopy, Rehabilitation, Therapy \& Technology 2011 3:19.

\section{Submit your next manuscript to BioMed Central and take full advantage of:}

- Convenient online submission

- Thorough peer review

- No space constraints or color figure charges

- Immediate publication on acceptance

- Inclusion in PubMed, CAS, Scopus and Google Scholar

- Research which is freely available for redistribution

Submit your manuscript at www.biomedcentral.com/submit
Biomed Central 